\title{
Radioactive Air Emissions \\ Notice of Construction \\ Debris Removal 105-KE Basin
}

Date Published

August 1995

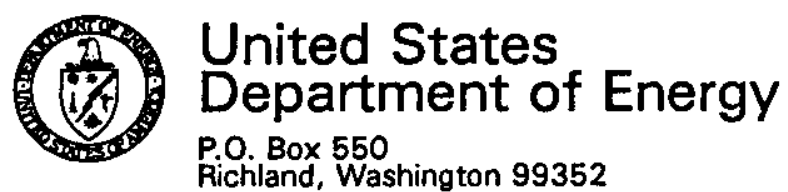

Richland, Washington 99352 


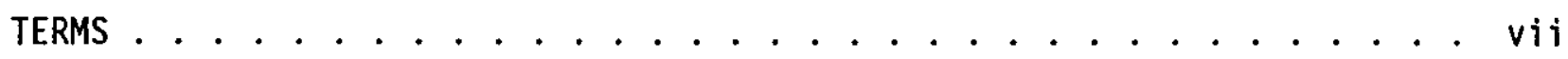

ABBREVIATIONS . . . . . . . . . . . . . . . . . . . . . . . . viii

METRIC CONVERSION CHART . . . . . . . . . . . . . . . . . . . . . ix

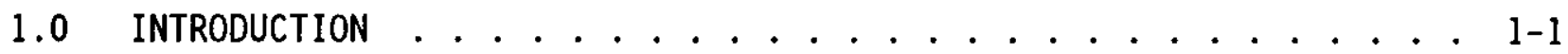

2.0 FACILITY LOCATION (Requirement 1) . . . . . . . . . . . . . 2-1

3.0 RESPONSIBLE MANAGER (Requirement 2) . . . . . . . . . . . . . . 3-1

4.0 TYPE OF PROPOSED ACTION (Requirement 3) . . . . . . . . . . . . . 4-1

5.0 STATE ENVIRONMENTAL POLICY ACT (Requirement 4) . . . . . . . . . . . 5-1

6.0 PROCESS DESCRIPTION (Requirements 5 and 7 ) . . . . . . . . . . . . 6-1

6.1 FACILITY OPERATIONS . . . . . . . . . . . . . . . . 6-1

6.2 FACILITY OVERVIEW ..................... . . . . 6-1

6.3 PROCESS DESCRIPTIONS .. . . . . . . . . . . . . . . . . . . 6-2

6.3.1 105-KE Basin Primary Water Treatment Recirculation
Loop Proposed Modifications........... 6-2

6.3.2 Fuel Movement Description . . . . . . . . . . . . . 6-3

6.3.3 Dose Reduction Description ............. 6-3

6.3.4 Sludge Movement Description . . . . . . . . . . 6-4

6.3.5 Debris Removal Description . . . . . . . . . . . 6-4

6.3.6 Specific Debris Removal Equipment and Operation . . . 6-6

6.3.6.1 Cutters ................ . 6-6

6.3.6.2 High-Pressure Water Jet System . . . . . . 6-6

6.3.6.3 Greenhouse System ........... 6-6

6.3.6.4 Packaging ................ 6-7

7.0 ANNUAL POSSESSION QUANTITY AND PHYSICAL FORM

(Requi rements 8, 10, 11, and 12) . . . . . . . . . . . . . . . . . 7-1

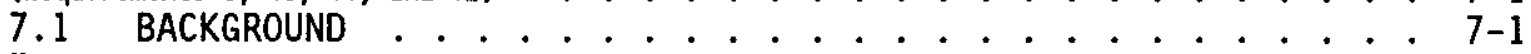

7.2 SOURCE TERM DESCRIPTION . . . . . . . . . . . . . . . . . . $7-2$

7.2.1 Fuel Elements . . . . . . . . . . . . . . . . . 7-2

7.2.2 Basin Water . . . . . . . . . . . . . . . 7-2

7.2.3 Sludge . . . . . . . . . . . . . . . . . . . 7-3

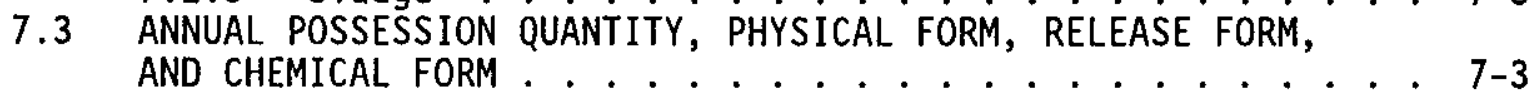

8.0 CONTROL SYSTEM (Requirement 6) ................. . . . . . . . .

8.1 FACILITY OVERVIEW . . . . . . . . . . . . . . . . . . . . . 8-1

8.2 CONTROL EQUIPMENT . . . . . . . . . . . . . . . . . . . . . 8-1

8.2.1 Passive System .................. . . 8-1

50

8.2.2 Active Systems 


\section{CONTENTS (cont)}

8.2.2.1 Heat Removal System - Primary

(Existing Configuration) ........ 8-1

8.2.2.2 Heat Removal System - Primary

(Proposed Configuration) . . . . . . 8-2

8.2.2.3 Sand Filter System - Secondary

(Existing Configuration) ....... . 8-2

8.2.2.4 Sand Filter System - Secondary

(Proposed Configuration) .. . . . . . 8-3

8.3 OPERATIONAL CONTROLS ................. 8-3

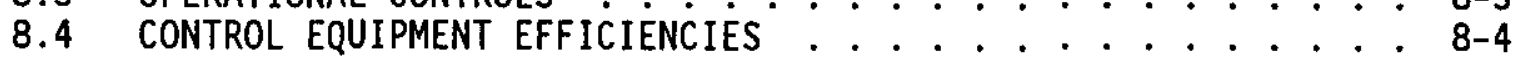

9.0 MONITORING SYSTEM (Requirement 9)................. 9-1

9.1 AIRBORNE DISCHARGE POINTS ................ . . . . . . .

9.2 SAMPLING SYSTEM .................... . . . . .

10.0 RELEASE RATES (Requirement 13) . . . . . . . . . . . . . . . . 10-1

10.1 PROJECTED EMISSIONS BASED ON 40 CFR 61, APPENDIX D ... . . 10-1

10.2 PROJECTED EMISSIONS BASED ON GOOD ENGINEERING JUDGEMENT . $:$. $10-1$

10.3 ANNUAL EMISSIONS ................... 10-3

11.0 OFFSITE IMPACT (Requirement 14 and 15) ................. 11-1

12.0 FACILITY LIFETIME (Requirement 17) . . . . . . . . . . . . . 12-1

13.0 TECHNOLOGY STANDARDS (Requirements 18) ................ 13-1

14.0 REFERENCES .......................... . . . . . . . . .

APPENDIX

A DISCUSSION OF BEST AVAILABLE RADIONUCLIDE

CONTROL TECHNOLOGY .................... APP A-i

\section{FIGURES}

2-1. Hanford Site .................... . . . .

2-2. Location of the 105-KE Basin within the 100-K Area . . . . . . . F2-2

6-1. General Facility Layout and Overview of the Underwater

Canister Cleaning Station and Greenhouse ............ . F6-1

6-2. Basin Water Level and Fuel Movement Diagram . . . . . . . . . . . F6-2

6-3. Debris Removal Greenhouse . . . . . . . . . . . . . . . . . F6-3

6-4. Schematic of Hydraulic Cutters . . . . . . . . . . . . . . . F6-4

6-5. Underwater Canister Cleaning Station . . . . . . . . . . F6-5 


\section{FIGURES (cont)}

8-1. Schematic Diagram of 105-KE Basin Water Treatment Systems ..... F8-1

9-1. Fixed Head Sampler Positions ..... . . . . . . . . . . . F9-1

\section{TABLES}

6-1. Estimated 105-KE Basin Debris and Canister Waste Volumes ..... T6-1

7-1. Calculated 105-KE Basin Fuel and Cobalt-60 Activity and Annual Possession Quantity ............. . . T7-1

7-2. Calculated 105-KE Basin Sludge Activity . . . . . . . . . T7-2

7-3. Physical Form, Release Form, and Chemical Form . . . . . . . . T7-3

8-1. Average Radionuclide Removal Efficiencies of the 105-KE Basin Water Treatment System Components . . . . . . . . . T8-1

10-1. Calculated Emissions for the Fuel and Cobalt-60 Based on Appendix D . . . . . . . . . . . T10-1

10-2. Good Engineering Judgment Projected Emissions using Fixed Head Sampler (RV11) Data . . . . . . . . . . . T10-2

10-3. Radioactive Air Emissions Measured at 105-KE Basin in Calendar Year $1994 \ldots$. . . . . . . . . . . . . . .

11-1. Total Effective Dose Equivalent to the Maximaliy Exposed Individual Using Projected Emissions Based on 40 CFR 61, Appendix D, Methodology and CAP-88 Dose Conversion Factors . . . T11-1

11-2. Total Effective Dose Equivalent to the Maximally Exposed Individual Using CAP-88 Dose Conversion Factors for the Good Engineering Judgment . . . . . . . . . . . . T11-2

11-3. Total Effective Dose Equivalent to the Maximally Exposed Individuat Using CY 1994 Emissions, using CAP-88 Dose Conversion Factors .............. . . Tll-3 
DOE/RL-95-65, Rev. 0

$08 / 95$

1

2

3

4

This page intentionally left blank. 


\section{TERMS}

ALARA as low as reasonable achievable

CFR Code of Federal Regulations

DF decontamination factor

$\mathrm{DOH} \quad$ Washington State Department of Health

10

11 Ecology

Washington State Department of Ecology

HEPA

high-efficiency particulate air

heating, ventilation, and air conditioning

ion exchange column

ion exchange module

17 IXM

18

19

ME I

maximally exposed individual

21 NOC

notice of construction

23 RCRA

Resource Conservation and Recovery Act of 1976

25 SEPA

26 SNM

27 SPR

28

29 TEDE

30

31 WAC

32

(Washington) State Environmental Policy Act of 1971

special nuclear material

single pass reactor

total effective dose equivalent

Washington Administrative Code 


$\begin{array}{rl}1 & \\ 2 & \\ 3 & \\ 4 & \mathrm{Ci} \\ 5 & \mathrm{Ci} / \mathrm{day} \\ 6 & \mathrm{Ci} / \mathrm{yr} \\ 7 & \mathrm{C}^{\circ} \\ 8 & \\ 9 & \mathrm{Kg} \\ 10 & \mathrm{kPa} \\ 11 & \\ 12 & \mathrm{mrem} \\ 13 & \mathrm{MTU} \\ 14 & \\ 15 & \mathrm{rem} \\ 16 & \\ 17 & \mu \mathrm{Ci} / \mathrm{ml} \\ 18 & \mu \mathrm{Ci} / \mathrm{L}\end{array}$

\section{ABBREVIATIONS}

curies

curies per day

curies per year

degrees Celsius

\section{kilogram}

kitopascal

milliroentgen equivalent man

Metric Tonnes of Uranium

roentgen equivalent man

microcuries per milliliter

microcuries per liter 


\begin{tabular}{|c|c|c|c|c|c|}
\hline \multicolumn{6}{|c|}{ METRIC CONVERSION CHART } \\
\hline \multicolumn{6}{|c|}{$\begin{array}{l}\text { The following conversion chart is provided to the reader as a tool to ai } \\
\text { in conversion. } \\
\text { Into metric units } \\
\text { Out of metric units }\end{array}$} \\
\hline If you know & $\begin{array}{c}\text { Multiply } \\
\text { by }\end{array}$ & To get & If you know & $\begin{array}{l}\text { Multiply } \\
\text { by }\end{array}$ & To get \\
\hline \multicolumn{3}{|c|}{ Length } & \multicolumn{3}{|c|}{ Length } \\
\hline inches & 25.40 & mi11imeters & millimeters & 0.0393 & inches \\
\hline inches & 2.54 & centimeters & centimeters & 0.393 & inches \\
\hline feet & 0.3048 & meters & meters & 3.2808 & feet \\
\hline yards & 0.914 & meters & meters & 1.09 & yards \\
\hline miles & 1.609 & kilometers & kilometers & 0.62 & miles \\
\hline \multicolumn{3}{|c|}{ Area } & \multicolumn{3}{|c|}{ Area } \\
\hline $\begin{array}{l}\text { square } \\
\text { inches }\end{array}$ & 6.4516 & $\begin{array}{l}\text { square } \\
\text { centimeters }\end{array}$ & $\begin{array}{l}\text { square } \\
\text { centimeters }\end{array}$ & 0.155 & $\begin{array}{l}\text { square } \\
\text { inches }\end{array}$ \\
\hline square feet & 0.092 & $\begin{array}{l}\text { square } \\
\text { meters }\end{array}$ & $\begin{array}{l}\text { square } \\
\text { meters }\end{array}$ & 10.7639 & $\begin{array}{l}\text { square } \\
\text { feet }\end{array}$ \\
\hline $\begin{array}{l}\text { square } \\
\text { yards }\end{array}$ & 0.836 & $\begin{array}{l}\text { square } \\
\text { meters }\end{array}$ & $\begin{array}{l}\text { square } \\
\text { meters }\end{array}$ & 1.20 & $\begin{array}{l}\text { square } \\
\text { yards }\end{array}$ \\
\hline $\begin{array}{l}\text { square } \\
\text { miles }\end{array}$ & 2.59 & $\begin{array}{l}\text { square } \\
\text { kilometers }\end{array}$ & $\begin{array}{l}\text { square } \\
\text { kilometers }\end{array}$ & 0.39 & $\begin{array}{l}\text { square } \\
\text { miles }\end{array}$ \\
\hline $\begin{array}{l}\text { square } \\
\text { miles }\end{array}$ & 259 & hectares & hectares & 0.00391 & $\begin{array}{l}\text { square } \\
\text { miles }\end{array}$ \\
\hline acres & 0.404 & hectares & hectares & 2.471 & acres \\
\hline \multicolumn{3}{|c|}{ Mass (weight) } & \multicolumn{3}{|c|}{ Mass (weight) } \\
\hline ounces & 28.35 & grams & grams & 0.0352 & ounces \\
\hline pounds & 0.453 & kilograms & kilograms & 2.2046 & pounds \\
\hline short ton & 0.907 & metric ton & metric ton & 1.10 & short ton \\
\hline \multicolumn{3}{|c|}{ Volume } & \multicolumn{3}{|c|}{ Volume } \\
\hline $\begin{array}{l}\text { fluid } \\
\text { ounces }\end{array}$ & 29.57 & milliliters & milliliters & 0.03 & $\begin{array}{l}\text { fluid } \\
\text { ounces }\end{array}$ \\
\hline quarts & 0.95 & liters & liters & 1.057 & quarts \\
\hline gallons & 3.79 & Titers & liters & 0.26 & gal1ons \\
\hline cubic feet & 0.03 & $\begin{array}{l}\text { cubic } \\
\text { meters }\end{array}$ & $\begin{array}{l}\text { cubic } \\
\text { meters }\end{array}$ & 35.3147 & cubic feet \\
\hline cubic yards & 0.76 & $\begin{array}{l}\text { cubic } \\
\text { meters }\end{array}$ & $\begin{array}{l}\text { cubic } \\
\text { meters }\end{array}$ & 1.308 & $\begin{array}{l}\text { cubic } \\
\text { yards }\end{array}$ \\
\hline \multicolumn{3}{|c|}{ Temperature } & \multicolumn{3}{|c|}{ Temperature } \\
\hline Fahrenheit & $\begin{array}{l}\text { subtract } \\
32 \text { then } \\
\text { multiply } \\
\text { by } 5 / 9 \text { ths }\end{array}$ & CeTsius & Celsius & $\begin{array}{l}\text { multiply } \\
\text { by } \\
9 / 5 \text { ths, } \\
\text { then add } \\
32\end{array}$ & Fahrenheit \\
\hline
\end{tabular}

39

40

41

Source: Engineering Unit Conversions, M. R. Lindeburg, PE., Second Ed., 1990, Professional Publications, Inc., Belmont, California. 
DOE/RL-95-65, Rev. 0

08/95

This page intentionally left blank. 
DOE/RL-95-65, Rev. 0

$08 / 95$

This page intentionally left blank. 


\subsection{FACILITY LOCATION (Requirement 4)}

Name and address of the facility, and location (lat.and long.) of the emission unit.

The 105-KE Basin is located within the 105-KE Reactor structure in the 100-K Area of the Hanford Site. The 100-K Area is approximately 40 kilometers northwest of the city of Richland, Washington. Figure 2-1 shows the location of the 100-K Area within the Hanford Site and Figure 2-2 shows the location of the 105-KE Basin within the 100-K Area. The Washington State Plane Coordinates for the approximate center of the 105-KE Basin are as follows:

Latitude: $146717.1 \mathrm{~N} \quad$ Longitude: $569184.3 \mathrm{E}$

Address: U.S. Department of Energy, Richland Operations Office Hanford Site 100-K Area, 105-KE Basin

Richland, Washington 99352. 
DOE/RL-95-65, Rev. 0

08/95

This page intentionally left blank. 


\section{RADIOACTIVE AIR EMISSIONS NOTICE OF CONSTRUCTION}

\subsection{INTRODUCTION}

The 105-KE Basin contains 1,150 Metric Tonnes of Uranium (MTU) of $N$ Reactor fuel, along with less than half a MTU of single pass reactor (SPR) fuel. In addition to the spent nuclear fuel (SNF) in the 105-KE Basin, extensive quantities of debris and a substantial amount of sludge have accumulated in the basin. The 105-KE Basin fuel and sludge are not encapsulated and, as a result, corroding fuel has produced contamination products that are deposited on the basin walls, floor, and equipment. The contamination products produce radiation dose exposures to the workers. To decrease worker exposures, this Notice of Construction (NOC) describes dose reduction modifications under consideration to mitigate worker radiation exposure from the basin walls and exposed piping.

The major equipment egress paths from the basin (the dummy elevator pit and the south loadout pit) are blocked completely with debris and/or empty canisters. Therefore in addition to dose reduction, this NOC also describes debris removal activities and equipment.

Recently, the primary water treatment system has been without mechanical filtration capabilities. This NOC describes planned modifications to the primary water treatment system to restore mechanical filtration by restarting the cartridge filters.

The proposed modifications described in this NOC are expected to commence in the Fall of 1995.

Finally, the NOC describes two other basin activities, fuel and sludge movement, that are expected to be routine in the future. 


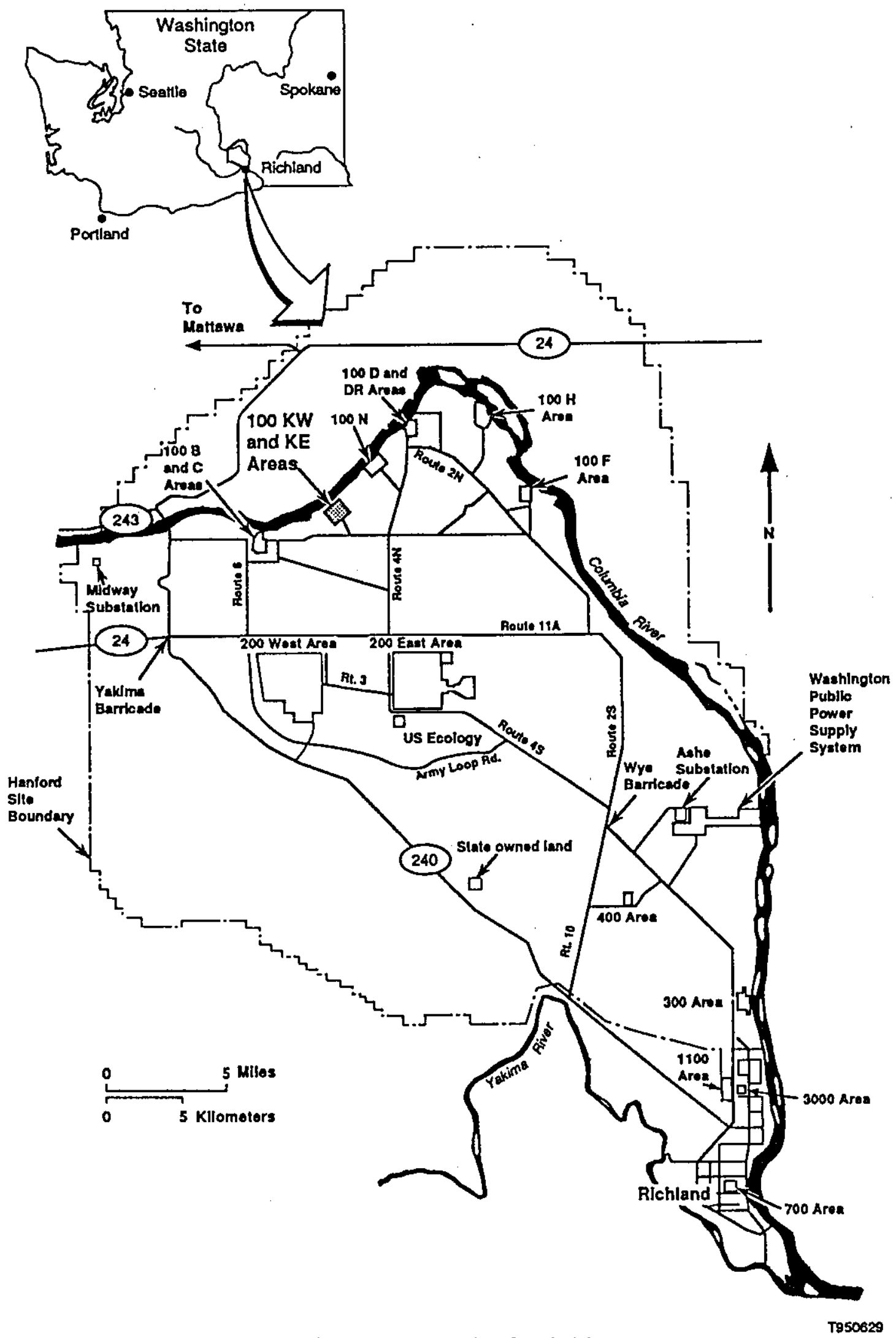

Figure 2-1. Hanford Site. 
DOE/RL-95-65, Rev. 0

$08 / 95$

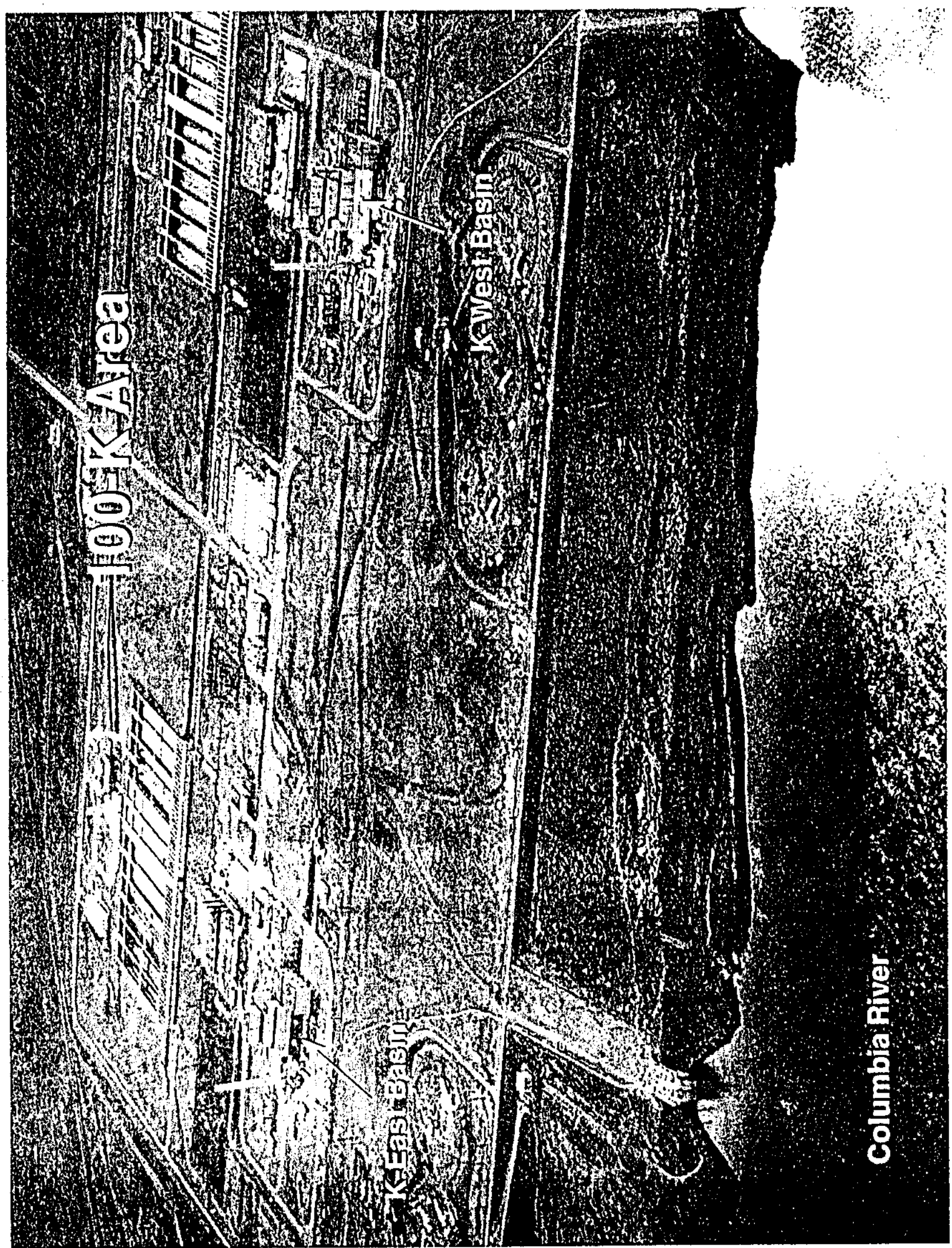

Figure 2-2. Location of the 105-KE Basin within the 100-K Area. 


\subsection{RESPONSIBLE MANAGER (Requirement 2)}

Name, title, address, and phone number of the responsible manager.

The responsible manager's name and address are as follows:

Ms. E. D. Sellers, Division Director Spent Nuclear Fuels Project Division U.S. Department of Energy Richland Operations Office Mail Stop S7-41

P.0. Box 550

Richland, WA 99352

(509) 373-9860. 
DOE/RL-95-65, Rev. 0

08/95

This page intentionally left blank. 


\subsection{TYPE OF PROPOSED ACTION (Requirement 3)}

Identify the type of proposed action for which this application is submitted.

The proposed action is considered a significant modification to the existing operations at the 105-KE Basin in accordance with WAC 246-247-030 (25). 
DOE/RL-95-65, Rev. 0

$08 / 95$

This page intentionally left blank. 
DOE/RL-95-65, Rev. 0

$08 / 95$

This page intentionally left blank. 
$\mathrm{DOE} / \mathrm{RL}-95-65$, Rev. 0

08/95

\subsection{PROCESS DESCRIPTION (Requirements 5 and 7 )}

\section{Describe the chemical and physical processes upstream of the emission unit. \\ 7. Provide conceptual drawings showing all applicable control technology components from the point of entry of radionuclides into the vapor space to release to the environment.}

\subsection{FACILITY OPERATIONS}

Fuel storage operations have been continuous since 1975 in the 105-KE Basin. Routine sampling is conducted to ensure that water quality is maintained to preserve the fuel and to protect human health and the environment. Instrumentation for water level, $\mathrm{pH}$, temperature, and radiation monitoring has been maintained and operated for fuel storage operations.

\subsection{FACILITY OVERVIEW}

The 105-KE Basin is a rectangular, reinforced concrete basin measuring 38 meters long by 20 meters wide by 6.4 meters deep with three main storage bays, separated by concrete partitions open at each end; two loadout pits; viewing pits; and a discharge chute. Structures for receiving fuel are at the west end where the railroad tracks enter through a large roll-up door providing access to the loadout pit. A 30-ton bridge crane is used for iifting casks from the railcar into the loadout pit. A metal grating is suspended over the entire basin, 6.4 meters above the basin floor (1.5 meters over the nominal water level) to provide a working surface from which operators maneuver the fuel canisters. Canisters are moved by using a hoist and monorail system that runs throughout the 105-KE Basin.

The main storage bay floor is equipped with racks designed to house fuel assembly canisters. The canisters are stored directly on the floor, surrounded by the storage racks that maintain the canisters in a fixed geometric array. The existing canisters consist of two upright cylinders approximately 23 centimeters in diameter by 66 centimeters tall, made of aluminum or stainless steel, and joined by trunions to facilitate handling. A canister can hold a maximum of $14 \mathrm{~N}$ Reactor fuel elements.

The water level of the 105-KE Basin is maintained at 5 meters deep to cool the fuel and to provide a radiological shield for personnel. The water is circulated through two closed-10op water treatment systems. Detailed descriptions of these systems are provided in Section 8.0. The general layout is shown in Figure 6-1 and the water level in relation to the stored fuel is shown in Figure 6-2.

Approved safety specifications and operating limits for fuel storage at the 105-KE Basin, including criticality considerations, can be found in the operations safety requirements (WHC 1993d). 


\subsection{PROCESS DESCRIPTIONS}

The proposed activities and/or operations for primary water treatment system, debris removal, fuel and sludge movement for the 105-KE Basin are discussed.

\subsubsection{5-KE Basin Primary Water Treatment Recirculation Loop Proposed Modifications}

The primary water treatment recirculation loop consists of two cartridge filters, three ion exchange columns (IXCs), and a chiller. The cartridge filters and the IXCs, have been by-passed because of transuranic waste disposal issues and worker radiation exposure concerns. The secondary or skimmer water treatment system consists of a sand filter and two ion exchange modules (IXMs). With the cartridge filters out of service, the basin has been left with only the sandfilter for mechanical filtration. The planned modifications would restart the cartridge filters, isolate the IXCs, and route flow from the primary water treatment recirculation system to the IXMs. Essentially, the IXMs are being removed from the secondary or skimmer water treatment system. A schematic of the modified water treatment system is provided in Figure 8-1.

To restart the cartridge filters, the cartridge filters will be modified to accept filters with a geometry easier to handle and package for final disposal. The new design for the cartridge filters will feature collection of particulates on the inside, rather than the outside of the filters. The cartridge filters have a nominal pore rating of 5 to 10 microns.

Restarting the cartridge filters will require removing the existing cartridge filters that have been in-place since early 1993. The existing filters will be removed underwater and placed into an overpack container before removal from the basin water. The entire overpack will then be removed from the water, rinsed with demineralized water, allowed to drain, sealed with plugs and a high-efficiency particulate air (HEPA) filter vent and placed into a disposal container. The new cartridge filters will be disposed of in a similar manner. Finally to facilitate cartridge filter changeouts, the existing hoist will be replaced.

The proposed piping modifications consist of fabricating a spool piece to connect the IXMs into the primary water treatment recirculation system. This will increase the IXM piping diameter from 7.62 centimeters to 10.16 centimeters to allow additional flow and will accommodate parallel IXM operation, if desired. For proper operation and characterization, new instrumentation consisting of a conductivity probe, new sample point, and flow indicating totalizer, will be installed into shop fabricated outlet piping. The outlet piping will then be installed on the IXMs and will facilitate dual IXM operation, if desired.

For proper operation and characterization, new instrumentation will be installed on the cartridge filters. New instrumentation will consist of inlet pressure gauges, flow indication totalizers, and downcomer flow indicators. 
None of these activities will involve contaminated piping and will not have a potential to emit radionuclides to the air. In addition, the outlet pressure gauge will be replaced. A number of pressure transmitters will also be replaced that are considered replacement in kind.

In summary, the instrumentation changes proposed either will not increase the potential to emit radionuclides to the air or are considered replacement in kind. During the installation of the piping previously described, the emissions will be controlled by either decontaminating the work area to remove smearable contamination or by performing the work within glovebags or similar containment.

\subsubsection{Fuel Movement Description}

Fuel will be moved as needed (i.e., relocated underwater) to allow space for numerous activities in the 105-KE Basin to support ultimate fuel movement. Canisters will be moved via the hoist and monorail. A hook will be directed underwater by the operator to connect with the canister. Once the hook is connected, the operator will walk the canister to the desired location by sliding the hoist along the monorail. In accordance with special nuclear material accountability procedures, canisters will be moved one at a time. Radiological surveys will be performed routinely on the 105-KE Basin to determine the levels of contamination present and to direct decontamination as necessary. Safety requirements and mechanical stops will prevent the canisters from being lifted closer than 3.05 meters from the surface of the water. Fuel movement will be conducted per controls stated in Section 8.3.

\subsubsection{Dose Reduction Description}

The water in the 105-KE Basin directly contacts the untreated basin concrete walls. Operation of the 105-KE Basin has resulted in measurable radioactive contamination depositing on and leaching into the basin walls at the liquid/solid interface, as evidenced by dose rates measured near the walls. Because of the lack of water shielding near the surface, the dose rate to the workers on the grating near the walls is significant. The worker dose comes from the unshielded or lightly shielded cesium-137 that has leached into the concrete.

Activities are being evaluated to reduce the dose receive by workers in the 105-KE Basin. The water will be raised between 15 and 45 centimeters to add additional shielding for the worker. This modification to the 105-KE Basin is within the prescribed limits of the safety analysis report (SAR) (WHC 1994a). Two options are under consideration to minimize the reoccurrence of the dose problem at the basin water line. The first option would be to coat the walls with an epoxy before raising the water. The second option would be to clean the basin walls using a low pressure (less than 1,000 psi) water jet. The cleaning head would be shrouded to mitigate aerosol formation. After cleaning, the basin walls would be coated with epoxy. 
Wall cleaning and coating, if conducted, would be performed under the controls in Section 8.3.

\subsubsection{Sludge Movement Description}

Sludge encountered during cleanup activities will be relocated by underwater pumping to the weasel pit using a submersible pump. Collection and movement of sludge has been previously demonstrated at 105-KE Basin during barrier door installation. A flexible hose will collect sludge from the bottom of the basin and the sludge will be pumped at 200 to 750 liters per minute using the basin water as a carrier. The discharge from the pump will be directed into the weasel pit behind a 400 mesh screen. The pump effluent is discharged underwater, and above the settled sludge in the weasel pit to minimize resuspension. However, some particles do migrate through the weasel pit screen and become dispersed in the basin water. To minimize particle migration a solid barrier may be added to enhance settling in the weasel pit. This additional barrier is not designed to prevent water flow between the weasel pit and the main basin.

Retrieval of fuel particles, debris, and sludge will be controlled by covering the suction head with a 0.6 centimeter screen or by limiting the terminal flow velocity for heavy particulates over 0.6 centimeter in diameter. Fuel particles and debris smaller than 0.6 centimeter will be vacuumed with the sludge. The fuel left behind greater than 0.6 centimeter in diameter will be temporarily collected and placed in open-top fuel canisters. The remaining non-fuel debris, largely zirconium alloy fuel structural parts, will be packaged and disposed of as low-level waste. Debris that is difficult to pick up using existing tools will be raked into a pile for later removal.

All sludge movement will be performed in accordance with the controls stated in Section 8.3 .

\subsubsection{Debris Removal Description}

Debris is defined as anything (e.g., scrap, equipment, and material) that is over 0.6 centimeters that is not physicaliy attached to the basin, or any permanent structure within the basin, is not used for current or $p l$ anned operations or maintenance activity, and is not fuel. Debris would include such things as empty fuel canisters, old equipment (e.g., pumps, neutron detectors, other segregation equipment, etc.), hand tools, and miscellaneous nonirradiated scrap. Irradiated debris and 'hot' items reading greater than 100 mrem per hour on contact will be inventoried and staged until characterized, sized, and packaged for shielded transfer to a disposal container. It is anticipated that removing the debris early in the SNF program will result in less worker-hour expenditures and less worker-dose exposure for fuel relocation and decontamination and decommissioning activities.

Before removing debris from the water, the debris items will, at a 
pressure water jet, but the option of removing the canisters and transferring to another facility for cleaning and disposal is an option. If the canisters are to be cleaned underwater before removal from the basin, a high-pressure water jet system will be installed to perform this task, using the basin water pumped at pressures in the range of $1 \times 10^{7}$ Pascal with flow rates of 45 to 60 liters per minute. Using this type of cleaning system would not increase the basin water inventory and would minimize the generation of additional radiological waste resulting from cleaning operations. The high-pressure water jet system would require a source of 480 volts $A C, 3$ phase power from the 105-KE Power Distribution System or a portable generator. If a portable generator is required it will be located outside the 105-KE Basin structure and the power routed into the basin to the High Pressure Water Jet System.

The debris will be segregated according to size to aid in handling while submerged or in a greenhouse (Figure 6-3) before being packaged for disposal. The greenhouse, further described in Section 6.3.6.3, will employ glove ports so the operators can work outside the containment. Oversized debris such as handling equipment and pipes will be cut to an appropriate size by using a hydraulic cutter. The cutter will use hydraulic fluids approved for use at 105-KE basin. The cutter and the high-pressure water jet system are being performance tested at a cold test facility. 105-K Basin personnel would be trained to use the equipment at a cold test facility.

Debris will be rinsed with water obtained from the IXM discharge during removal and then bagged for disposal. Removal and bagging of debris will be conducted within a greenhouse (Figure 6-3). Debris that requires sizing to fit into a disposal container will be cut either under water with cutters or bagged, taped, and cut with cutters above water (as described previously).

Sampling and characterization of the removed debris will be performed in accordance with an approved solid waste acceptance criteria plan. The final characterization of the debris will be performed before transfer to the Solid Waste Operations Center (SWOC) to ensure all applicable regulatory requirements are met. The types of waste generated would include low-level radioactive, transuranic, and mixed. The waste will be disposed in accordance with regulatory requirements.

The majority of the debris that will be removed from the 105-KE Basin are empty fuel canisters (Table 6-1). Debris will be removed one piece at a time with a debris handling hoist into the greenhouse. The debris handling hoist will be administratively controlled to prohibit fuel movement. The greenhouse will surround the debris from the water line through the bagging operation. The greenhouse will be HEPA-filtered, and exhausted internally within the 105-KE Basin. The greenhouse exhaust will be designed, and operated in a manner to minimize disturbing existing surface contamination. The exhaust flowrate from the greenhouse will range from 3.5 to 15 cubic meters per minute. All debris removal activities will be conducted in accordance with controls of Section 8.3 . 50 The debris removal will take place in the basin as an ongoing 51 housekeeping activity. The first areas targeted for debris removal will be 
41

the pit areas. It is later expected that debris removal will occur as a secondary activity to other basin activities.

The initial mobilization and equipment setup will be in the center bay of the basin. Fuel will be relocated in the basin to clear an area for the debris removal equipment. As one area of the basin is cleaned out, the work area may be relocated to other areas to facilitate the work, consistent with ALARA and other ongoing basin operations.

Vacuuming and sweeping of small debris will be performed during each phase of the operation. Areas of the basin will be left as clean as possible after each operation. However, because of the presence of fuel and fuel racks in the center sections of the basin, small amounts of debris and sludge will be inaccessible during this operation and will be left for future cleanup.

Changes made to the 105-KE Basin during debris removal will be removal of selected grating and installation of a safety rail around any openings created. This work will involve decontaminating areas of the grating structure and then cutting by mechanical means. The greenhouse will be attached to the basin support system and will use the existing monorail system. The pump for the high pressure water jet system will be on a skid sitting behind the IXMs (Figure 6-1).

A portable generator (if required) will be placed outside the 105-KE Basin and power routed back to the equipment.

\subsubsection{Specific Debris Removal Equipment and Operation}

The monorail, hoist, and trolley will be used for transferring debris in the basin. Long handled tools used to manipulate items under water will be used as required. Additional equipment or tools will have operating procedures and use will require operator training.

6.3.6.1 Cutters. Control for the operation of the cutter will be provide via a hydraulic valve assembly (closed loop) that controls the cutter in both the forward (cutting) and reverse (release) direction. The motive fluid used in the cutter assembly is an approved compatible water soluble hydraulic fluid. The cutter will be used remotely underwater or dry (out of water) hand held (Figure 6-5).

6.3.6.2 High-Pressure Water Jet System. The pump will be on a skid sitting behind the IXMs. The high-pressure water jet system will be operated in two modes as either a fixed underwater canister cleaning station or as a hand held cleaning wand. The underwater station will be in the center bay of the basin. (Figure 6-5). The system will use water from the discharge area of the IXMs to reduce water additions to the basin. The cleaning wand will be operated mechanically and by an operator. The operator will be able to turn the wand and mechanical operation will move the wand up and down. The wand tip will remain at least 1.22 meters below the water at all times. 
6.3.6.3 Greenhouse System. Debris will be removed from the basin into a greenhouse. The debris will be removed with a debris removal handling hoist. A fuel handling hoist will not be used for removing debris. During removal from the water, debris will be rinsed with water obtained from the IXM discharge. The debris will be drip dried over a drip pan and the drip pan will have a drain hose leading back into the basin to return the collected water.

Personnel will perform debris handling and bagging from the outside of the greenhouse. Personnel will access debris via glove ports in the greenhouse. Personnel will wear required protective clothing and equipment as conditions require in the 105-KE Basin.

6.3.6.4 Packaging. Once the debris is bagged, the debris will be moved by hand truck to a package container located near the doors at the west end of the 105-KE Basin. 
DOE/RL-95-65, Rev. 0

$08 / 95$

$$
\begin{aligned}
& 1 \\
& 2 \\
& 3 \\
& 4 \\
& 5
\end{aligned}
$$

This page intentionally left blank. 


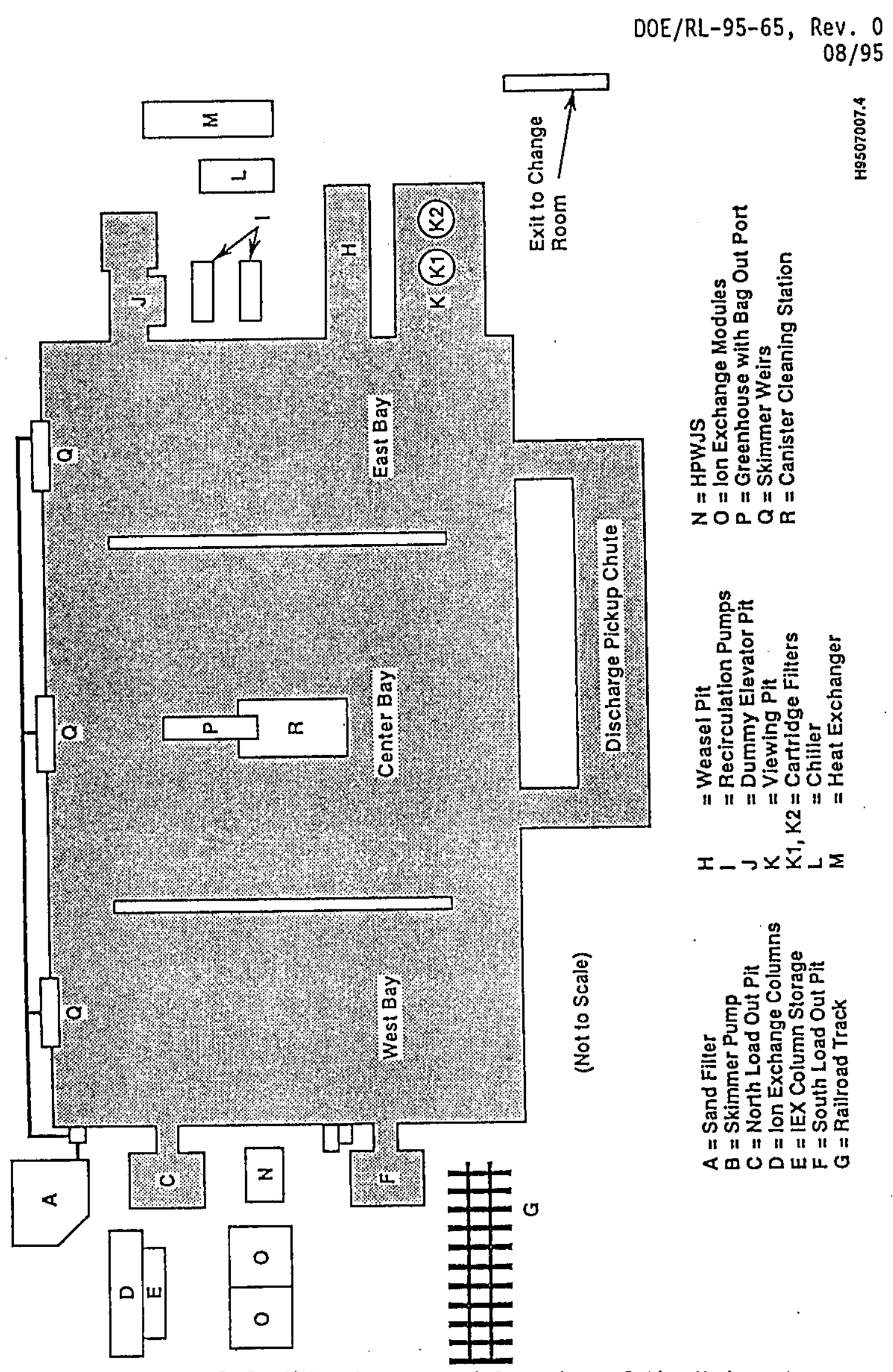

Figure 6-1. General Facility Layout and Overview of the Underwater Canister Cleaning Station and Greenhouse. 
DOE/RL-95-65, Rev. 0

$08 / 95$

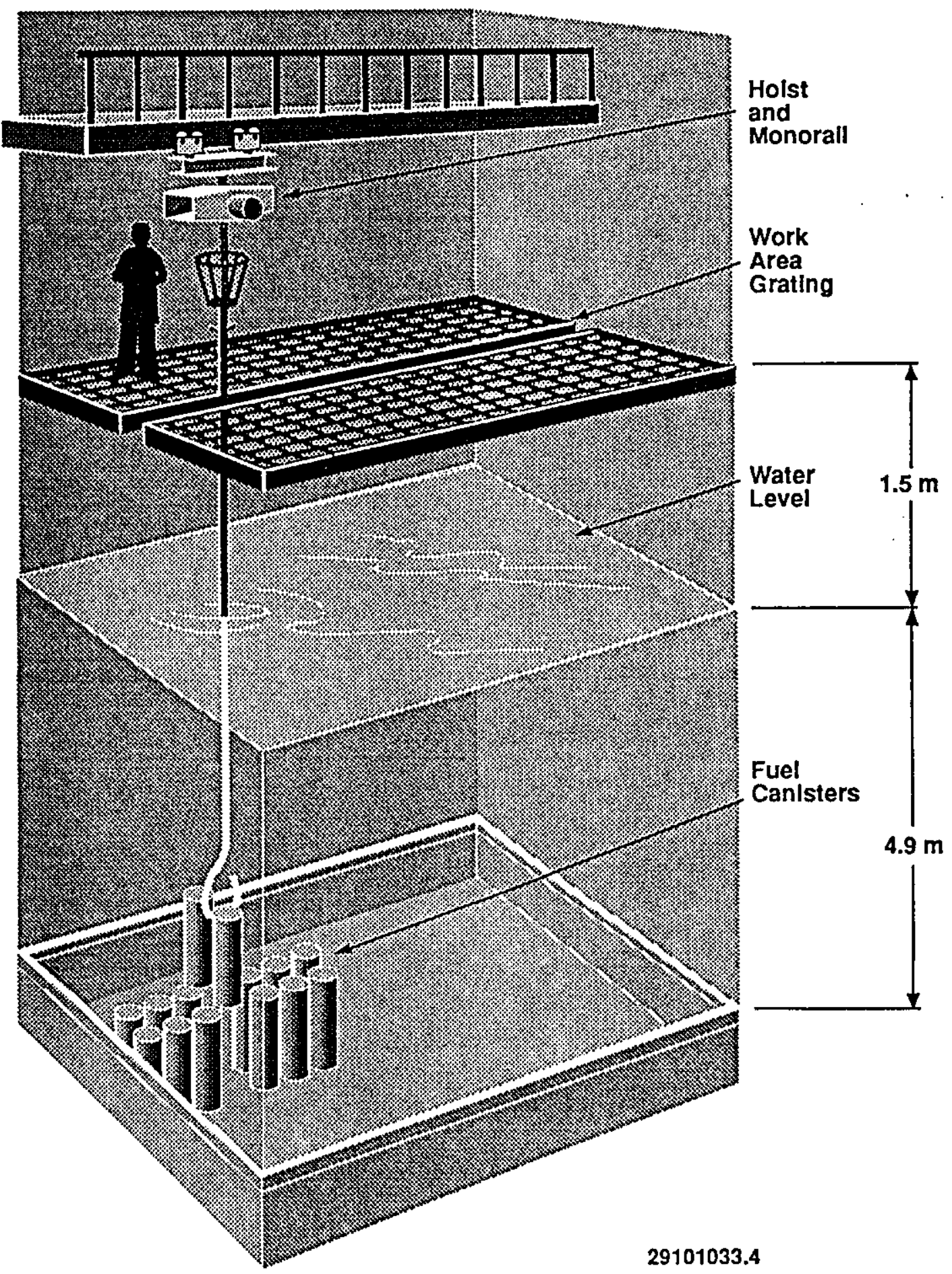

Figure 6-2. Basin Water Level and Fuel Movement Diagram. 
DOE/RL-95-65, Rev. 0

$08 / 95$



Figure 6-3. Debris Removai Greenhouse. 


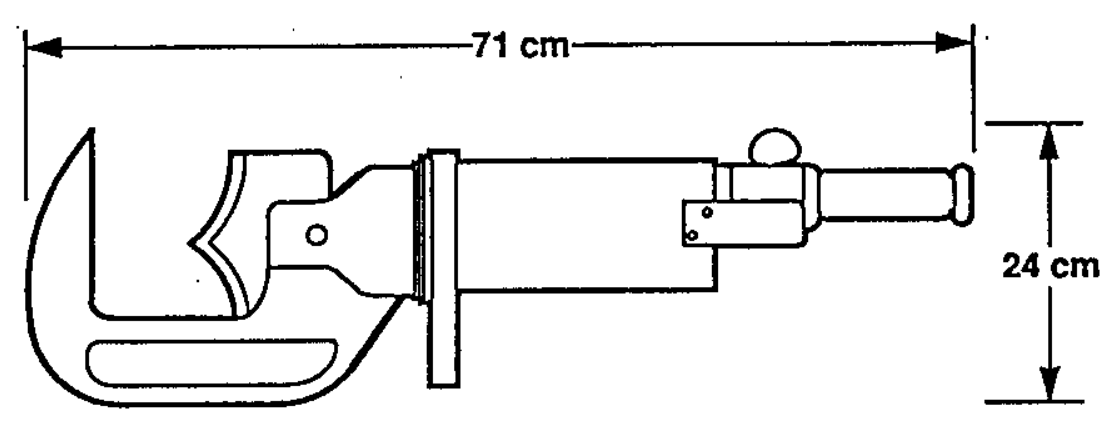

Width $12 \mathrm{~cm}$ (Not Shown)

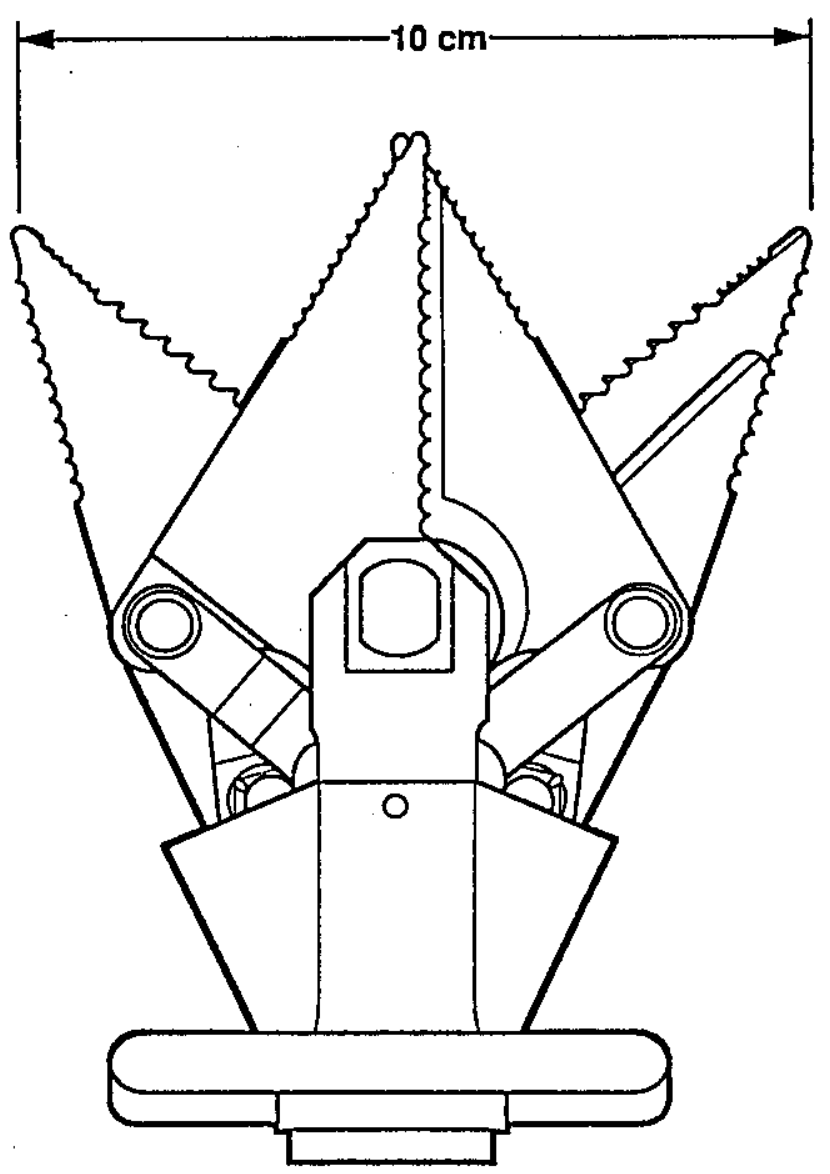

H9507007.1

Figure 6-4. Schematic of Hydraulic Cutters. 


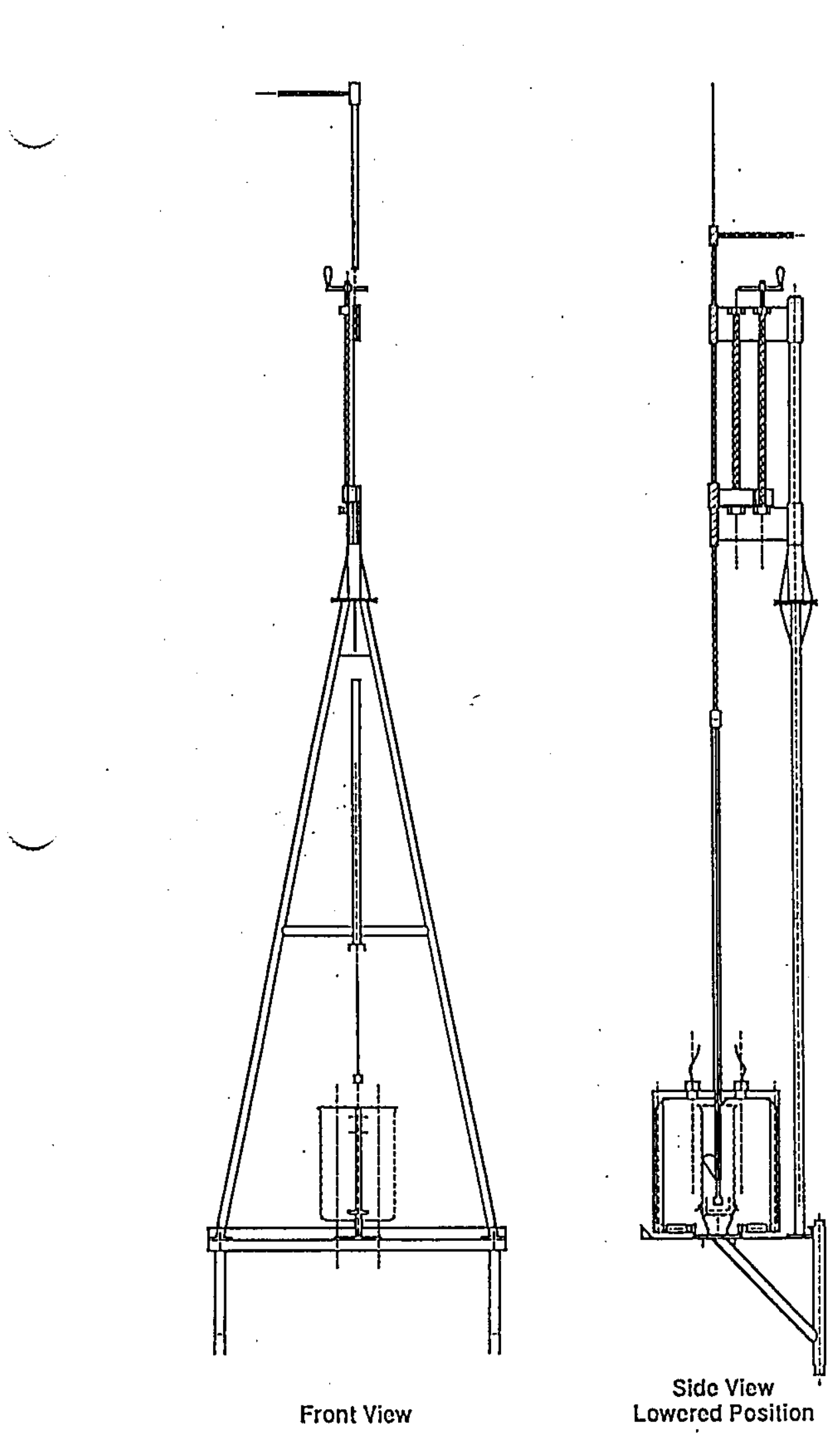

DOE/RL-95-65, Rev. 0
$08 / 95$

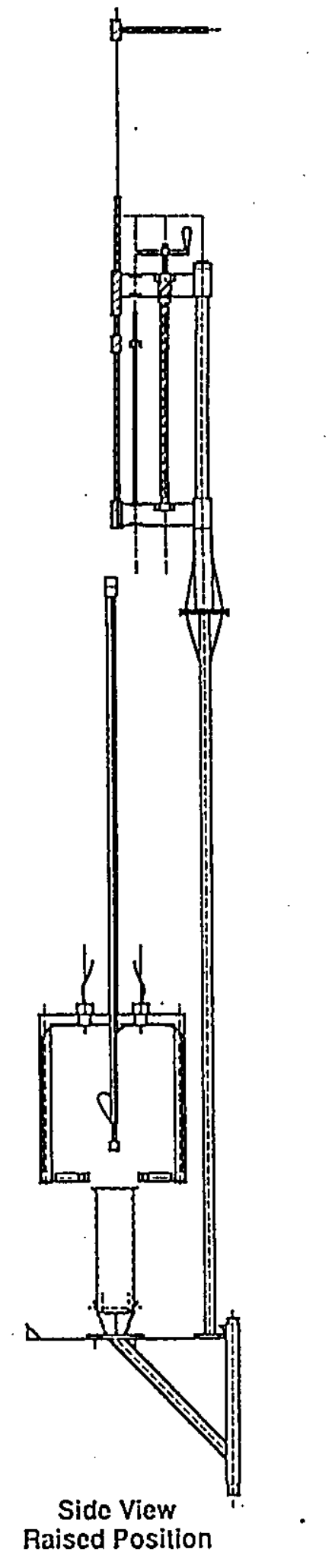

H9507007.5

Figure 6-5. Underwater Canister Cleaning Station. 
Table 6-1. Estimated 105-KE Basin Debris and Canister Waste Volumes.

\begin{tabular}{|c|c|c|}
\hline Description & Estimated volume & B-25 boxes needed \\
\hline $\begin{array}{l}\text { Estimated empty aluminum } \\
\text { canisters-1,200 }\end{array}$ & $100 \mathrm{~m}^{3}$ & 67 Boxes \\
\hline $\begin{array}{l}\text { Estimated Empty Stainless } \\
\text { Steel Canisters-600 }\end{array}$ & $50 \mathrm{~m}^{3}$ & 33 Boxes \\
\hline EMPTY CANISTER TOTALS & $150 \mathrm{~m}^{3}$ & 100 Boxes \\
\hline Other debris in main basin & $7 \mathrm{~m}^{3}$ & 3.6 Boxes \\
\hline $\begin{array}{l}\text { Other debris in dummy } \\
\text { elevator pit }\end{array}$ & $18 \mathrm{~m}^{3}$ & 8.9 Boxes \\
\hline $\begin{array}{l}\text { Other debris in tech } \\
\text { viewing pit }\end{array}$ & $6 \mathrm{~m}^{3}$ & 2.7 Boxes \\
\hline Other debris in weasel pit & $1 \mathrm{~m}^{3}$ & .4 Boxes \\
\hline $\begin{array}{l}\text { Abandoned equipment in } \\
\text { discharge chute }\end{array}$ & $3 \mathrm{~m}^{3}$ & $\begin{array}{l}1.3 \text { Boxes } \\
\text { (Repackaging } \\
\text { equipment left for } \\
\text { decontamination and } \\
\text { decommissioning) } \\
\end{array}$ \\
\hline OTHER DEBRIS TOTALS & $35 \mathrm{~m}^{3}$ & 17 Boxes \\
\hline DEBRIS AND CANISTERS TOTALS & $185 \mathrm{~m}^{3}$ & 117 Boxes \\
\hline
\end{tabular}




\title{
7.0 ANNUAL POSSESSION QUANTITY AND PHYSICAL FORM \\ (Requirements $8,10,11$, and 12)
}

\begin{abstract}
8. Identify each radionuclide that could contribute greater than ten percent of the potential to emit TEDE to the MEl, or greater than $0.1 \mathrm{mrem} / \mathrm{yr}$ potential to emit TEDE to the MEI.
\end{abstract}

10. Indicate the annual possession quantity for each radionuclide.

11. Indicate the physical form of each radionuclide in inventory: Solid, particulate solids, liquid, or gas.

12. Indicate the release form of each radionuclide in inventory: Particulate solids, vapor, or gas. Give the chemical form and ICRP 30 solubility class, if known.

This section provides background information on the 105-KE Basin; provides source term information for the fuel, sludge, and the basin water, and provides information on annual possession quantity, physical form, release form, and chemical form.

\subsection{BACKGROUND}

The 105-KE Basin contains approximately 1,150 MTU of $N$ Reactor fuel (approximately 3,700 canisters) and two baskets (the equivalent of five canisters) filled with aluminum-clad fuel assembilies from SPR. The $N$ Reactor fuel consists of slightly enriched metallic uranium completely enclosed and bonded to a layer of zirconium alloy (Zircaloy-2), also known as the cladding. The SPR fuel is very similar, except the fuel is of smaller dimensions and is clad in aluminum. The cladding is designed to provide a barrier against the escape of the radionuclide source term (fission products and fissile materials).

The $\mathrm{N}$ Reactor fuel was discharged between 1975 and 1987 . The fuel has decayed sufficiently to essentially eliminate iodine-131, as well as other short half-life radionuclides. Following discharge of the fuel from the $N$ Reactor, the $N$ Reactor fuel was allowed to cool for a minimum of 150 days in $\mathrm{N}$ Basin. The fuel was placed into open-top canisters, loaded into railcars, and transported to the 105-KE Basin for storage.

The fuel cladding integrity varies from undamaged cladding that retains the radionuclide source term, to fuel that has breached cladding from reactor defueling and subsequent handiing operations. The cladding breaches range from cracking to the complete separation of fuel elements into two or more parts. Once the cladding has been breached, and the basin water gains access to the radionuclide source term, the radionuclides in the fuel over time either dissolve or corrode slowly. For example, radionuclides with high solubilities such as cesium and strontium dissolve into the basin water and less soluble radionuclides are oxidized (corroded) and released from the fuel elements and are incorporated into the sludge. 


\subsection{SOURCE TERM DESCRIPTION}

The radionuclide inventory of the irradiated fuel is $9.3 \mathrm{MCi}$ (WHC 1993b). The irradiated fuel is the major source term in 105-KE Basin. The source term is presented in Table 7-1. The following sections provide a discussion on fuel elements, basin water, sludge, and the annual possession quantity.

\subsubsection{Fuel Elements}

The majority of the fuel stored in the 105-KE Basin was 0.95 weight percent enriched with the uranium-235 isotope before irradiation. Operating specifications prohibit the storage of higher enrichments. A small amount of natural uranium fuel (0.71 weight percent uranium-235) also is stored in the 105-KE Basin. Because the highly enriched fuel results in higher radionuclide levels for given irradiation and decay times, radionuclide levels were conservatively based on the entire inventory being 0.95 weight percent uranium-235 enriched fuet.

Approximately 850 MTU of the inventory were irradiated to fuel grade assay levels where the plutonium-240 content was allowed to increase to 12 percent of the total plutonium produced. The remaining 300 MTU of fuel were irradiated to weapon grade assay levels where the plutonium-240 content was allowed to increase to 6 percent. Because longer irradiation times increase the total radionuclide content of the fuel, the radionuclide content for conservatism, was based on the fuel grade assay levels.

To establish a conservative source term the following assumptions were used. The fuel discharge age was assumed to be 10 years and source term has been decayed to 10 years. Currently, the average age of the fuel (after discharge) is greater than 10 years. Additionally, the soluble radionuclides (cesium-137 and strontium-90) that are removed by the water treatment system have not been removed from the source term.

\subsubsection{Basin Water}

The water in the 105-KE Basin provides cooling and shielding. The sludge and fuel are covered by the $3.86 \times 10^{6}$ liters of water. Despite the size of the source term in the fuel and sludge, a relatively small fraction is present in the basin water. The source term of the 105-KE Basin water was calculated to be 56 curies in 1990 (WHC 1991a). Predominant isotopes present in the water were hydrogen-3 (21 curies), strontium-90 (15 curies), and cesium-137 (19 curies). The nonpredominant isotopes account for 1 curie. Lower levels of strontium-90 and cesium-137 are often achieved depending on the operation of the water treatment systems. Because the radionuclide source term in the water originates from fuel and no credit has been taken for the operation of the water treatment system, the radionuclide source term in the water is accounted for in Table 7-1.

The radionuclides of significance in the airborne emissions are known to be particulates that originate from the basin water. The primary mechanisms 
responsible for airborne contamination are transport at the water line of the basin, and suspension of surface contamination on basin floors, gratings, and tools (WHC 1993a).

\subsubsection{Sludge}

Original estimates concerning the sludge were extremely conservative and assumed the sludge was all radionuclide oxides from the fuel, even though it was recognized that much of the sludge is comprised of dirt, rust, and other non-fuel materials. There are still uncertainties associated with the sludge and those uncertainties will be resolved when further sampling and characterization are performed.

A recent estimate has been made of the source term inventory of the sludge (WHC 1995b). The estimate accounts for sludge source terms by areas; in the various basin pits, in fuel canisters, and on the bas in floor. The total source term of radioactivity in the sludge is presented in Table 7-2. The source term was estimated using sludge depth surveys to determine the volume (52.01 cubic meters of sludge), density measurements, percent solids analytical data, and the measurements of radioactivity per gram for each isotope in the various areas of the basin. Where data did not exist, estimates were applied to obtain the final totals. Most of the radioactivity in the sludge results from corrosion of the fuel. An exception to this is the cobalt-60. Cobalt-60 originated from corrosion of structural materials (steel and wear resistant materials) in the reactor. The cobalt-60 source term in the sludge has been included in both Tables 7-1 and 7-2.

\subsection{ANNUAL POSSESSION QUANTITY, PHYSICAL FORM, RELEASE FORM, AND CHEMICAL FORM}

The annual possession quantity is shown in Table 7-1. For purposes of calculating a potential to emit, a good engineering judgment was made for projecting the offsite doses to maximally exposed individual. To determine the amount of particulates available for release from the fuel, a comparison or a ratio of the quantity of americium-241 in the sludge to the quantity of americium-241 in the fuel was performed. From Table 7-2, 762 curies of americium-241 in the sludge was divided by 62,900 curies of americium-241 in the total source from Table 7-1. To arrive at a percentage, the ratio was multiplied by 100 . The result was $1.2 \%$.

Hence, sludge sampling shows a relatively minor amount of the fuel corroded and dispersed as particulate matter (sludge). Most of the fuel remains as a metallic solid. To be on the conservative side for determining the physical state adjustment factor, the ratio of $1.2 \%$ for particulates was increased to $2 \%$. The rest of the fuel $(98 \%)$ was assumed to be an intact solid.

Physical form, release form, chemical form, and radionuclides that could contribute greater than 10 percent of the potential to emit total effective dose equivalent to the maximally exposed individual are identified in 
DOE/RL-95-65, Rev. 0

1 Table 7-3. For ICRP 30 solubility, default solubility classes from the

2 U.S. Environmental Protection Agency (EPA)-approved code CAP-88 (EPA 1990)

3 were used for all radionuclides (WHC 1991b). 
Table 7-1. Calculated 105-KE Basin Fuel and Cobalt-60 Activity and Annual Possession Quantity.

\begin{tabular}{|c|c|c|}
\hline 4 & Radionuclide & $\begin{array}{c}\text { Inventory } \\
\text { (Ci) }\end{array}$ \\
\hline 5 & ${ }^{3} \mathrm{H}$ & $5.65 E+02$ \\
\hline 6 & ${ }^{60} \mathrm{CO}^{\mathrm{a}}$ & $2.86 E+01$ \\
\hline 7 & ${ }^{85} \mathrm{Kr}$ & $2.28 E+05$ \\
\hline 8 & ${ }^{90} \mathrm{Sr}$ & $2.40 \mathrm{E}+06$ \\
\hline 9 & ${ }^{106} \mathrm{Ru}$ & $1.20 \mathrm{E}+05$ \\
\hline 10 & ${ }^{134} \mathrm{Cs}$ & $1.61 E+04$ \\
\hline 11 & ${ }^{137} \mathrm{Cs}$ & $2.48 E+06$ \\
\hline 12 & ${ }^{144} \mathrm{Ce}$ & $4.14 E+05$ \\
\hline 13 & ${ }^{234} \mathrm{U}$ & $4.85 E+02$ \\
\hline 14 & ${ }^{235} \mathrm{U}$ & $8.79 E+01$ \\
\hline 15 & ${ }^{238} \mathrm{U}$ & $3.94 E+02$ \\
\hline 16 & ${ }^{238} \mathrm{Pu}$ & $1.35 \mathrm{E}+04$ \\
\hline 17 & ${ }^{239 / 240} \mathrm{Pu}$ & $8.65 E+04$ \\
\hline 18 & ${ }^{241} \mathrm{Pu}$ & $3.45 E+06$ \\
\hline 19 & ${ }^{241} \mathrm{Am}^{\mathrm{b}}$ & $6.29 E+04$ \\
\hline 20 & Total & $9.27 E+06$ \\
\hline
\end{tabular}

${ }^{60} \mathrm{Co}$ also included in Table 7-2.

b A11 actinides (except $\mathrm{Pu}-241$ ) were estimated to be $1.63 \mathrm{E}+05 \mathrm{Cj}$. Based on air emissions measured for calendar year 1994 at 105-KE Basin, $8.3 \%$ were Pu-238, $53.1 \%$ were $\mathrm{Pu}-239 / 240$ and $38.6 \%$ were $\mathrm{Am}-241$. It is assumed the actinides are in the same proportion as those measured in air emissions.

The following radionuclides contributed to less than $1 \%$ of the radionuclide source term; ${ }^{89} \mathrm{Sr}$, ${ }^{95} \mathrm{Zr}$, ${ }^{95} \mathrm{Nb}$, and ${ }^{103} \mathrm{Ru}$. (Curie concentrations were in the E-05 to E-09 range.) 
Table 7-2. Calculated 105-KE Basin Sludge Activity.

3
4
5
6
7
8
9
10
11
12
13
14

\begin{tabular}{|c|c|}
\hline Radionuclide & $\begin{array}{l}\text { Inventory } \\
\text { (Ci) }\end{array}$ \\
\hline${ }^{60} \mathrm{Co}$ & $2.86 E+01$ \\
\hline${ }^{90} \mathrm{Sr}$ & $1.33 E+03$ \\
\hline${ }^{137} \mathrm{Cs}$ & $1.01 E+03$ \\
\hline${ }^{238} \mathrm{Pu}$ & $6.61 E+01$ \\
\hline${ }^{239 / 240} \mathrm{Pu}$ & $4.03 E+02$ \\
\hline${ }^{241} \mathrm{Pu}$ & $5.66 E+03$ \\
\hline${ }^{241} \mathrm{Am}$ & $7.62 E+02$ \\
\hline Total & $9.27 E+03$ \\
\hline
\end{tabular}

13

14 
1 Table 7-3. Physical Form, Release Form, and Chemical Form.

\begin{tabular}{|l|l|l|l|}
\hline Radionuclide & Physical form & \multicolumn{1}{|c|}{ Release form } & Chemical form \\
\hline${ }^{3} \mathrm{H}$ & solid & vapor & water \\
${ }^{60} \mathrm{Co}$ & particulate solid & particulate solid & oxide \\
${ }^{85} \mathrm{Kr}$ & solid & gas & elemental \\
${ }^{89} \mathrm{Sr}$ & solid & particulate solid/solid & UNK \\
${ }^{90} \mathrm{Sr}$ & solid & particulate solid/solid & UNK \\
${ }^{95} \mathrm{Zr}$ & solid & particulate solid/solid & UNK \\
${ }^{95} \mathrm{Nb}$ & solid & particulate solid/solid & UNK \\
${ }^{103} \mathrm{Ru}$ & solid & particulate solid/solid & UNK \\
${ }^{106} \mathrm{Ru}$ & solid & particulate solid/solid & UNK \\
${ }^{134} \mathrm{Cs}$ & solid & particulate solid/solid & UNK \\
${ }^{137} \mathrm{Cs}$ & solid & particulate solid/solid & UNK \\
${ }^{144} \mathrm{Ce}$ & solid & particulate solid/solid & UNK \\
${ }^{234} \mathrm{U}$ & solid & particulate solid/solid & UNK \\
${ }^{235} \mathrm{U}$ & solid & particulate solid/solid & UNK \\
${ }^{238} \mathrm{U}$ & solid & particulate solid/solid & UNK \\
${ }^{239} \mathrm{Pu}$ & solid & particulate solid/solid & UNK \\
${ }^{240} \mathrm{Pu}^{\mathrm{b}}$ & solid & particulate solid/solid & UNK \\
${ }^{241} \mathrm{Am}^{\mathrm{b}}$ & solid & particulate solid/solid & UNK \\
\hline
\end{tabular}
aadionuclides identified as UNK or unknown, form various complex
compounds.

bRadionuclides that could contribute greater than 10 percent of the potential to emit total effective dose equivalent to the maximally exposed individual. 


\subsection{CONTROL SYSTEM (Requirement 6)}

Describe the existing and proposed (as applicable) abatement technology. Describe the basis for the use of the proposed system. Include expected efficiency of each control device, and the annual average volumetric flow rate in meters cubed $/ \mathrm{sec}$ for the emission unit.

\subsection{FACILITY OVERVIEW}

The 105-KE Basin does not provide for inlet supply air and exhausted air is not high-efficiency particulate air (HEPA) filtered. Air is exhausted from the building via roof vents, two over the basin and two over the high bay area. The combined air flow from the four roof vents is 24 cubic meters per second.

Refer to Section 6.2 for overview of the 105-KE Basin.

Radioactive airborne emissions from the 105-KE Basin originate from the basin water. Figure 9-1 details the location of the vents in the roof of the basin. The primary mechanisms responsible for airborne contamination are transport at the water line of particulates from the basin and suspension of surface contamination on floors, gratings, and tools (WHC 1993a). The radionuclides are emitted through the vents to the environment.

\subsection{CONTROL EQUIPMENT}

The existing radionuclide control equipment consists of passive and active systems for controlling the source term. The application of these radionuclide controls are in accordance with ANS-57.7 (ANS 1988).

\subsubsection{Passive System}

The passive system consists of the $3.86 \times 10^{6}$ liters of water that covers the irradiated fuel. The water precludes the radionuclide source term from becoming directly airborne as might occur if the water were absent. The water also provides radiation shielding.

\subsubsection{Active Systems}

To reduce radionuclide concentrations in the basin water, two water treatment systems are employed: the primary system is a heat removal system with filtering and ion exchange capabilities and the secondary system is a sand filter and ion exchange system. As mentioned in Section 6.3.1 of this NOC, portions of these systems have not been operated and modifications to the systems are planned. For clarification, to the reader, text will describe the existing configurations and the proposed configurations. A schematic of the water treatment system after the modifications is provided in Figure 8-1.

8.2.2.1 Heat Removal System - Primary (Existing Configuration). The primary recirculation system (heat removal system) consists of two redundant pumps, 
1 two redundant cartridge filters, an air cooled chiller, and three parallel 2 IXCs. The main recirculation system draws water through an underwater intake 3 header from three locations along the north wall, one in each of the three 4 bays, at approximately mid-depth of the basin. After treatment, the system returns treated water to three discharge lines along the south wall, one in each of the three bays. The main recirculation system pumps are operated alternately to provide approximately 1.7 E+03 liters per minute flow.

The two cartridge filters are operated alternately to remove particulates from the water upstream of the chiller and IXCS. The cartridge filters have a nominal pore rating of 10 microns, and are removed from service and disposed after a single use. The cartridge filters have been valved out of service for over 2 years because of radiation exposure issues related to techniques used for filter element changeout.

After being filtered, approximately half of the flow is routed through a heat exchanger to remove approximately $210 \mathrm{kilowatts}$ to lower the water temperature. The temperature of the basin water is important because it affects the corrosion rates of the fuel and the solubility of radionuclides. The basin temperature must be maintained between $5.5^{\circ} \mathrm{C}$ and $32^{\circ} \mathrm{C}$ per process standards. The water temperature is generally maintained around $9^{\circ} \mathrm{C}$ to minimize corrosion rates and radionuclide solubility. Measurements of the dissolution rates or increases in cesium-137 concentrations per day have been made at various temperatures when the water treatment system was not operating. The dissolution rate varied from 1.0 curies per day at $8^{\circ} \mathrm{C}$ to 2.0 curies per day at $14^{\circ} \mathrm{C}$ to 3.0 curies per day at $21^{\circ} \mathrm{C}$ (WHC $1995 \mathrm{a}$ ). Downstream of the chiller, the chilled water is recombined with the rest of the filtered water from the cartridge filters.

Approximately 1.1 E+03 liters per minute of the recombined filtered and cooled water is returned directly to the pool, and approximately $5.7 \mathrm{E}+02$ liters per minute is routed through a bank of three parallel IXCs before being returned to the pool. Each IXC is an unshielded, carbon steel vessel approximately 46-centimeter diameter by 1.5 meter tall, and has a flow capacity of approximately 1.9 E+02 liters per minute. Although several different types of resin have been used historically in the $K$ Basins, mixed bed (cation and anion) resins were used predominately in the last several years that the IXCS were on line. The IXCS are removed from service and disposed after a single usage, usually on the basis of cesium removal efficiency. The IXCs have been valved out of service for several years because of worker radiation exposure and disposal issues.

8.2.2.2 Heat Removal System - Primary (Proposed Configuration). After the proposed water treatment system modifications are complete, the IXCs will be isolated and removed. The cartridge filters will be operational with updated filters that are easier to change. Downstream of the cartridge filters and chiller, water will be routed to two IXMs that can be operated either in parallel or separately with one in reserve.

8.2.2.3 Sand Filter System - Secondary (Existing Configuration). This water treatment system is used for the purpose of removing floating materials from the surface of the water and to remove any large particles suspended in the 
water. This system consists of a single pump, a sand filter, and two IXMs. Basin water is drawn in from three adjustable weirs located along the north wall of the 105-KE basin and returned after treatment to either the south loadout pit or along the west wall of the basin.

The system provides approximately 1.4 E+03 liters per minute flow through a sand filter. After passing through the filter, approximately $7.6 \mathrm{E}+02$

liters per minute is returned directly to the pool, and approximately $6 \mathrm{E}+02$ liters per minute is routed through either of two IXMs before being returned to the pool. The sand filter has a nominal pore rating of 100 microns, and a flow capacity larger than the rest of the system. The sand filter is backwashed as needed, with the backwash being collected in the north loadout pit.

One IXM is normally in use, with the other in reserve. Each IXM contains six IX vessels, which are configured in parallel. The IX vessels have a flow capacity of approximately I E+02 liters per minute each, for a total IXM flow capacity of approximately $6 \mathrm{E}+02$ liters per minute. The IXMs are large (218-centimeter $\times 202$-centimeter) self-contained mixed bed resin systems. Although several different types of resin have been used historically in the $K$ Basins, zeolites and mixed bed resins have predominately been used in the last several years. The IXMs are removed from service and disposed after a single usage, usually on the basis of TRU content or cesium removal efficiency.

\subsubsection{Sand Filter System - Secondary (Proposed Configuration). After the} proposed water treatment system modifications are complete, the skimmer system (sand filter system) will be isolated from the IXMs, and filtered water from the sand filter will be routed directly back to the basin.

\subsection{OPERATIONAL CONTROLS}

The water treatment systems contain ion exchange components for removal of soluble radionuclides and particulate filters for removal of particulate radionuclides. These components can affect emission levels because their operation, and basin activities, determine the quantity of radionuclides that are present in the water at a given time.

The basin water is relatively insensitive to short term shutdowns of the water treatment system. The largest single factor in the basin water quality is the continuing operation of the IXM and the timely changeout of an IXM before depletion. Under favorable conditions, the cesium-137 concentrations in the basin water can range from 1 microcurie per 1 iter to 3 microcuries per liter, although higher values have been experienced. For the concentration of cesium-137 in the basin water increase significantly an outage of the IXMs would need to extend over a period of several days. If the IXMs are out of service the basin water cesium-137 concentration increases on the order of 0.5 microcurie per day (cesium-137 dissolution rate equals 2.0 curies per day). 


\subsection{CONTROL EQUIPMENT EFFICIENCIES}

The water treatment systems contain ion exchange components for removal of soluble radionuclides and particulate filters for removal of particulate radionuclides. Removal efficiencies are presented in Table 8-1.

The removal efficiencies for the IXMs decrease with increasing run time. The IXMs are changed out when sampling indicates the removal efficiency for cesium-137 has decreased from 99 percent to 70 percent. Time between changeouts varies and depends on basin water quality.

The filters in the cartridge filter cells will be modified and will achieve performance at least as good as the previous system. The previous cartridge filters removed approximately 12 percent of the total plutonium concentrations in the inlet stream. The particulate filters show negligible removal efficiencies for the dissolved cesium and strontium as would be expected. 


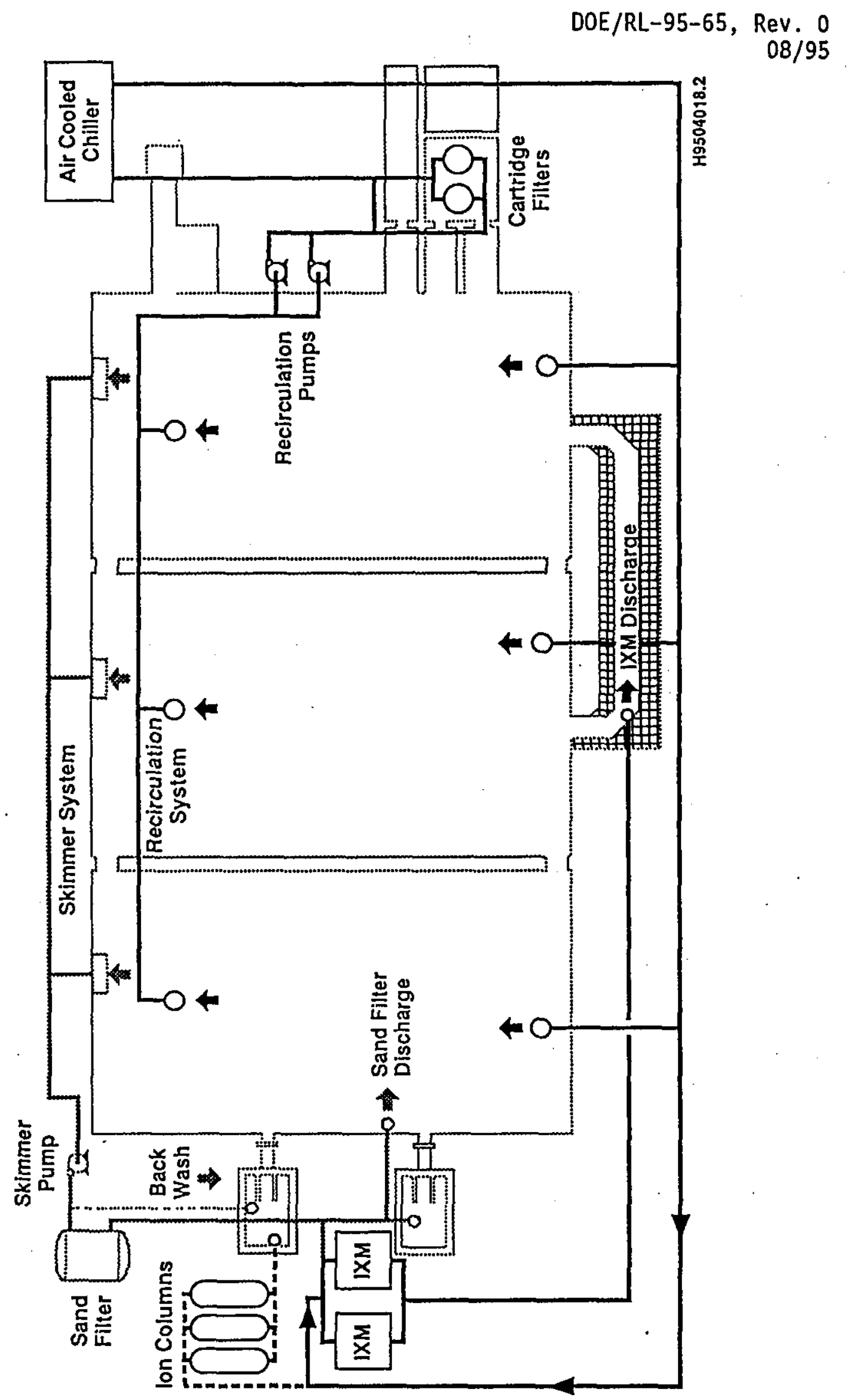

Figure 8-1. Schematic Diagram of 105-KE Basin Water Treatment Systems. 
Table 8-1. Average Radionuclide Removal Efficiencies of the 105-KE Bas in Water Treatment System Components.

3

4

\begin{tabular}{|c|c|c|c|}
\hline Radionuclide & $\begin{array}{c}\text { Ion exchange } \\
\text { module } \\
(\%)\end{array}$ & $\begin{array}{c}\text { Sand filter } \\
(\%)\end{array}$ & $\begin{array}{c}\text { Cartridge filter } \\
\text { cells } \\
(\%)\end{array}$ \\
\hline Strontium & 93.5 & Negligible & Negligible \\
\hline Cesium & 49 & Negligible & Negligible \\
\hline Plutonium & 81 & Less than 12 & 12 \\
\hline
\end{tabular}

8

9

10

Source: WHC 1993b. 


\subsection{MONITORING SYSTEM (Requirement 9)}

Identify the effluent monitoring system for the proposed control system. Describe each piece of monitoring equipment and its monitoring capability, including detection limits, for each radionuclide that could contribute greater than ten percent of the potential to emit TEDE to the MEl, or greater than $0.1 \mathrm{mrem} / \mathrm{yr}$ potential to emit TEDE to the MEl, after controls. Describe the method for monitoring or calculating those radionuclide emissions, Describe the method with detail sufficient to demonstrate compliance with the applicable requirements.

\subsection{AIRBORNE DISCHARGE POINTS}

The 105-KE Basin does not provide for inlet supply air and exhausted air is not HEPA filtered. Air is exhausted from the building via roof vents, two over the basin and two over the transfer high bay area. The combined air flow from the four roof vents is 24 cubic meters per second (WHC 1993a).

\subsection{SAMPLING SYSTEM}

The sampling system inside the 105-KE Basin consists of four fixed head samplers. The design of the fixed head samplers allows the filter head to be lowered or elevated for safe change-out and sample collection. The particulate filters from the four samplers are collected weekly. The particulate filters are delivered to Quanterra Environmental Services of Richland, Washington. Quanterra Environmental Services performs a total alpha/beta analyses on the particulate filters. The contractual detection limits for Quanterra Environmental Services are l picocurie per sample, for a typical sample this is approximately 4.4 E-16 microcuries per milliliter. Weekly filters are composited for a monthly gamma scan strontium-90, americium-241, and plutonium isotopic analysis. The particulate radionuclides contributing 10 percent or more of the total effective dose equivalent from 105-KE Basin are plutonium-239/240 and americium-241. Of the air emissions measured for calendar year 1994 at 105-KE Basin, 8.3 percent of the actinides were plutonium-238, 53.1 percent were plutonium-239/240, and 38.6 percent were americium-241 (DOE-RL 1995).

The four samplers are located as follows, two are located over the 105-KE Basin and two are located in the transfer high bay area. Two of the samplers over the 105-KE Basin are positioned directly in front of roof vent 11 and roof vent 10 , the inlet to the exhaust fans. The filter assembly is attached to an adjustable support that is extended to the inlet of the fan about 3.4 meters above the floor. The third and fourth samplers are in the transfer high bay area near exhaust fans roof vent 6 and roof vent 7 . The filter assembly for the high bay samplers are approximately 6 .I meters above the floor. Figure 9-1 identifies the relative position of these fixed head samplers.

The sampler system design eliminates any sample line loss concerns. The particulate filter employed is a 47 millimeters glass fiber filter with a 91 percent capture efficiency for particles with a diameter greater than 0.3 micron. The sample filter assembly is connected to a vacuum pump via 
1 plastic tubing. Because the particulate filter is upstream of the plastic 2 tubing, the particulate filter is not influenced by the tubing. The sample 3 pumps are equipped with a flow regulator. The nominal sample flow rate is a 40.06 cubic meter per minute.

Operational checks of the exhaust fans and the sample pumps are performed daily. In the event a fan or sample pump is found not operating or is de-energized for any reason, the sampler is turned off until the exhaust fan

9 is returned to service. The operability information for the samplers and 10 exhaust fans is logged and reported to monitoring program personnel. The 11 sample pump flow rate is measured quarterly and recorded using a calibrated 12 National Institute of Standards and Technology traceable flow meter. 




Figure 9-1. Fixed Head Sampler Positions. 


\subsection{RELEASE RATES (Requirement 13)}

New emission units: Give predicted release rates without any emissions control equipment (the potential to emit) and with the proposed control equipment using the efficiencies described in requirement (6). Modified emission units: Give predicted release rates without any emission control equipment (the potential to emit) and with the existing and proposed control equipment using the efficiencies described in requirement (6). Provide the latest year's emissions data or emissions estimates.

The following provides projections of emissions based on (1) the methodology prescribed in 40 CFR 61, Appendix D, and (2) good engineering judgment, and actual emissions data.

\subsection{PROJECTED EMISSIONS BASED ON 40 CFR 61, APPENDIX D}

Table 10-1 presents the projected annual emissions using 40 CFR 61 , Appendix D, methodology. Radionuclides used in this projection are those that have been identified in Table 7-1 representing the fuel element activity and the sludge activity. The inventory of each radionuclide was multiplied by a physical state adjustment factor to calculate a projected annual release.

To determine the amount of particulate available for release from the fuel, a comparison or a ratio of the quantity of americium-241 in the sludge to the quantity of americium-241 in the fuel was performed. From Table 7-2, 762 curies of americium-241 in the sludge was divided by 62,900 curies of americium-241 in the total source from Table 7-1. To arrive at a percentage, the ratio was multiplied by 100 . The result was 1.2 percent.

Hence, sludge sampling shows a relatively minor amount of the fuel corroded and dispersed as particulate (sludge). Most of the fuel remains as a metallic solid. To be on the conservative side for determining the physical state adjustment factor, the ratio of 1.2 percent for particulates was increased to 2 percent. The rest of the fuel (98 percent) was assumed to be an intact solid.

\subsection{PROJECTED EMISSIONS BASED ON GOOD ENGINEERING JUDGEMENT}

The assumptions and the data for the good engineering judgement (Table 4-2) presented in the 105-KE encapsulation NOC (DOE-RL 1993) were reviewed and are still valid with the exception of the americium-241 data. Comparing the 1992 air effluent sampling data to 1994 air effluent sampling data (Table 10-3) the americium-241 data appears to be 70 . A potential reason may be that sampling for americium-241 recently had been initiated. Therefore, to provide a bounding case, the 1992 americium-241 data were multiplied by a factor of 1.60 . The factor of 1.60 was derived as follows.

The ratio of isotopes as projected in Table 4-2 (DOE-RL 1993),

$$
{ }^{241} \mathrm{Am} /{ }^{239 / 240} \mathrm{Pu}=1.4 \mathrm{E}-5 \mathrm{Cj} / 3.1 \mathrm{E}-5 \mathrm{Cj}=45.2 \% \text {. }
$$


The ratio as determined from recent data (1994 air effluent data) has increased,

$$
{ }^{241} \mathrm{Am} /{ }^{239 / 240} \mathrm{Pu}=5.6 \mathrm{E}-6 \mathrm{Ci} / 7.7 \mathrm{E}-6 \mathrm{Ci}=72.7 \% .
$$

Therefore, to account for the larger proportion of ${ }^{241} \mathrm{Am}$, dividing $72.7 \%$ by $45.2 \%$ results in a factor of 1.60 .

The following discussion for generating Table 4-2 of the 105-KE Encapsulation NOC (DOE-RL 1993) has been reproduced and will be referred to as Table 10-2. Table 10-2 was developed from actual data obtained from the fixed head sampler (RVII) shown in Figure 9-1. Section 9.0 presents a description of the fixed head sampler. These data were obtained during the sampling period from October through December 1992.

This sampling period was selected for two reasons. First, the extensive sludge pumping and sludge debris raking during this time resulted in increased suspension of radionuclides in the basin water. Second, the radionuclides in the water were further elevated by shutdown of the water treatment system during October and the first two weeks of December 1992. The shutdowns of the water treatment systems were necessary to replace the existing water-cooled chiller with a new air-cooled chiller and to minimize the generation of transuranic waste associated with operation of the IXCS. The combination of the increase in suspended sludge and the necessity of the water treatment system shutdowns during this period resulted in radionuclide concentrations in the water that afforded a bounding case projection of air emissions.

Table 10-2 presents the individual radionuclide concentrations, averaged for the sampling period 0ctober through December 1992. The projected annual release for each radionuclide was calculated by multiplying the individual radionuclide concentration by the maximum annual flow rate with all four vent fans operating continuously. Formulas for the flow rate and projected annual emission (with the exception of hydrogen-3) are as follows:

Annual Flow Rate:

(60 minute/hour) $\left(8,760\right.$ hours/year) $\left(50,274 \mathrm{ft}^{3} / \mathrm{min}\right)$

$\left(28.32 \mathrm{~L} / \mathrm{ft}^{3}\right)(1,000 \mathrm{~mL} / \mathrm{L})=7.5 \mathrm{E}+14 \mathrm{~mL} /$ year

Expected Annual Emission:

$$
\text { (concentration } \mu \mathrm{Ci} / \mathrm{mL})\left(10^{-06} \mathrm{Cj} / \mu \mathrm{ci}\right)(7.5 \mathrm{E}+14 \mathrm{~mL} / \text { year) }=\mathrm{Ci} / \text { year }
$$

The projected annual emission for tritium was calculated by multiplying the concentration of tritium in the basin water by the evaporation rate of the basin water to yield the amount of tritium released. 
Concentration of $3 \mathrm{H}$ in basin water (WHC 1993b) $=3.0 \mathrm{E}-03 \mu \mathrm{ci} / \mathrm{mL}$

Evaporation rate of basin water $=41.6 \mathrm{~L} / \mathrm{hr}$

$(3.0 \mathrm{E}-03 \mu \mathrm{ci} / \mathrm{mL})(4.16 \mathrm{E}+04 \mathrm{~mL} / \mathrm{hr})(8,760 \mathrm{hr} /$ year $)(1 \mathrm{E}-06 \mathrm{Ci} / 1 \mu \mathrm{Ci})=$

\section{$1.2 \mathrm{Ci} /$ year of ${ }^{3} \mathrm{H}$}

\subsection{ANNUAL EMISSIONS}

The following are results of monitoring 105-KE Basin in calendar year 1994, using the sampling system described in Section 9.0. As indicated in Table 10-3, the actual release for all radionuclides is 1.63 E-04 curies.

The total exhaust air flow assumed was $7.5 \mathrm{E}+14$ milliliters for the year. 
DOE/RL-95-65, Rev. 0
$08 / 95$

This page intentionally left blank. 
Table 10-1. Calculated Emissions for the Fuel and Cobalt-60 Based on Appendix $D^{a}$.

\begin{tabular}{|c|c|c|c|}
\hline Radionuclide & Inventory $(\mathrm{C} i)$ & $\begin{array}{l}\text { Physical state } \\
\text { adjustment factor }\end{array}$ & $\begin{array}{c}\text { Projected } \\
\text { emissions ( } i)\end{array}$ \\
\hline${ }^{3} \mathrm{H}$ & $5.65 E+02$ & 1 & $5.65 E+02$ \\
\hline${ }^{60} \mathrm{Co}$ & $2.86 E+01$ & 0.001 & $2.86 E-02$ \\
\hline${ }^{85} \mathrm{Kr}$ & $2.28 E+05$ & 1 & $2.28 E+05$ \\
\hline${ }^{90} \mathrm{sr}$ & $2.40 E+06$ & 2.1 E-05 & $5.03 E+01$ \\
\hline${ }^{106} \mathrm{Ru}$ & $1.20 \mathrm{E}+05$ & $2.1 \mathrm{E}-05$ & $2.52 E+00$ \\
\hline${ }^{134} \mathrm{Cs}$ & $1.61 E+04$ & $2.1 E-05$ & $3.4 \quad E-01$ \\
\hline${ }^{137} \mathrm{Cs}$ & $2.48 E+06$ & $2.1 E-05$ & $5.2 \quad E+01$ \\
\hline${ }^{144} \mathrm{Ce}$ & $4.14 E+05$ & $2.1 \mathrm{E}-05$ & $8.69 E+00$ \\
\hline${ }^{234} \mathrm{U}$ & $4.85 E+02$ & $2.1 \mathrm{E}-05$ & 1.0 E-02 \\
\hline${ }^{235} \mathrm{U}$ & $8.79 E+01$ & $2.1 \mathrm{E}-05$ & $1.84 E-03$ \\
\hline${ }^{238} U$ & $3.94 E+02$ & 2.1 E-05 & $1.0 \quad E-02$ \\
\hline${ }^{238} \mathrm{Pu}$ & $1.35 E+04$ & $2.1 \mathrm{E}-05$ & $2.8 \quad E-01$ \\
\hline${ }^{239 / 240} \mathrm{Pu}$ & $8.65 E+04$ & $2.1 \mathrm{E}-05$ & $1.81 E+00$ \\
\hline${ }^{241} \mathrm{Am}$ & $6.29 E+04$ & $2.1 \mathrm{E}-05$ & $1.32 E+00$ \\
\hline${ }^{241} \mathrm{Pu}$ & $3.45 E+06$ & $2.1 \mathrm{E}-05$ & $7.23 E+01$ \\
\hline Total & $9.27 E+06$ & & $2.29 E+05$ \\
\hline
\end{tabular}

a Source: 40 CFR 261.

b The eguation used for the physical state adjustment factor (excluding ${ }^{85} \mathrm{Kr},{ }^{3} \mathrm{H}$, and ${ }^{60} \mathrm{Co}$ ) is as follows:

$$
(0.02)(1 E-03)+(0.98)(1 E-06)=2.1 E-05 .
$$

Example calculation for ${ }^{3} \mathrm{H}$ :

$5.65 \mathrm{E}+02 \mathrm{Ci}$ of ${ }^{3} \mathrm{H} \times 1=5.65 \mathrm{E}+02 \mathrm{Ci}$ of ${ }^{3} \mathrm{H}$.

Example calculation for ${ }^{90} \mathrm{Sr}$ :

$$
2.4 \mathrm{E}+06 \mathrm{Ci} \text { of }{ }^{90} \mathrm{Sr} \times(0.000021)=5.03 \mathrm{E}+01 \mathrm{Ci} \text { of }{ }^{90} \mathrm{Sr} \text {. }
$$

The following radionuclides contributed to less than $1 \%$ of the radionuclide source term; ${ }^{89} \mathrm{Sr},{ }^{95} \mathrm{Zr},{ }^{95} \mathrm{Nb},{ }^{103} \mathrm{Ru}$. (Curie concentrations were in the E-05 to E-09 range.) 
Table 10-2. Good Engineering Judgment Projected Emissions using Fixed Head Sampler (RV11) Data.

3

$$
4
$$

5

6

7

8

9

10

11

12

\begin{tabular}{|l|c|c|}
\hline Radionuclide & $\begin{array}{c}\text { Average concentration } \\
\text { (October 1992 to } \\
\text { December } 1992) \\
(\mu \mathrm{Ci} / \mathrm{m} 1)\end{array}$ & $\begin{array}{c}\text { Projected annual } \\
\text { emissions (Ci/yr) }\end{array}$ \\
\hline${ }^{60} \mathrm{Co}$ & $1.5 \mathrm{E}-14$ & $1.1 \mathrm{E}-05$ \\
\hline${ }^{90} \mathrm{Sr}$ & $7.5 \mathrm{E}-13$ & $5.6 \mathrm{E}-04$ \\
\hline${ }^{106} \mathrm{Ru}$ & $3.3 \mathrm{E}-14$ & $2.4 \mathrm{E}-05$ \\
\hline${ }^{137} \mathrm{CS}$ & $6.4 \mathrm{E}-13$ & $4.8 \mathrm{E}-04$ \\
\hline${ }^{238} \mathrm{Pu}$ & $6.9 \mathrm{E}-15$ & $5.2 \mathrm{E}-06$ \\
\hline${ }^{239 / 240} \mathrm{Pu}$ & $4.2 \mathrm{E}-14$ & $3.1 \mathrm{E}-05$ \\
\hline${ }^{241} \mathrm{Am}$ & $2.9 \mathrm{E}-14$ & $2.2 \mathrm{E}-05$ \\
\hline${ }^{241} \mathrm{Pu}$ & $5.3 \mathrm{E}-14$ & $4.0 \mathrm{E}-05$ \\
\hline & & $1.2 \mathrm{E}-03$ \\
\hline
\end{tabular}

${ }^{\text {TThe }}$ projected annual emissions presented in this table do not include tritium $\left({ }^{3} \mathrm{H}\right)$. Multiplying the concentration of tritium in the basin water by the evaporation rate of the basin water yields the amount of tritium released.

Concentration of ${ }^{3} \mathrm{H}$ in basin water (WHC 1993b) $=3.0 \mathrm{E}-03 \mu \mathrm{Ci} / \mathrm{mL}$.

Evaporation rate of the basin water $=41.6$ liters per hour.

$$
\left(3.0 \times 10^{-03} \frac{\mu \mathrm{Ci}}{\mathrm{mL}}\right]\left[4.16 \times 10^{04} \frac{\mathrm{mL}}{\mathrm{h}}\right]\left[8,760 \frac{\mathrm{h}}{\text { year }}\right]\left[\frac{10^{-06} \mathrm{Ci}}{1 \mu \mathrm{Ci}}\right]=1.2 \frac{\mathrm{Ci}}{\text { year }}
$$


Table 10-3. Radioactive Air Emissions Measured at 105-KE Basin in Calendar Year 1994.

\begin{tabular}{|l|c|}
\hline \multicolumn{1}{|c|}{ Radionuclide } & Release (Ci) \\
\hline${ }^{90} \mathrm{Sr}$ & $4.6 \mathrm{E}-05$ \\
${ }^{60} \mathrm{Co}$ & $3.6 \mathrm{E}-07$ \\
${ }^{155} \mathrm{Eu}$ & $1.1 \mathrm{E}-06$ \\
${ }^{106} \mathrm{Ru}$ & $2.3 \mathrm{E}-06$ \\
${ }^{125} \mathrm{Sb}$ & $9.1 \mathrm{E}-07$ \\
${ }^{137} \mathrm{Cs}$ & $9.6 \mathrm{E}-05$ \\
${ }^{154} \mathrm{Eu}$ & $1.6 \mathrm{E}-06$ \\
${ }^{238} \mathrm{Pu}$ & $1.2 \mathrm{E}-06$ \\
${ }^{239 / 240} \mathrm{Pu}$ & $7.7 \mathrm{E}-06$ \\
${ }^{241} \mathrm{Am}$ & $5.6 \mathrm{E}-06$ \\
\hline \multicolumn{2}{|c|}{} \\
\hline
\end{tabular}

16 


\subsection{OFFSITE IMPACT (Requirement 14 and 15)}

14. Identify the MEI by distance and direction from the emission unit(s). The MEI is determined by considering distance, windrose data, presence of vegetable gardens, and meat or milk producing animals at unrestricted areas surrounding the emission unit.

15. Calculate the TEDE to the MEl using an approved procedure (see WAC 246-247-085). For each radionuclide identified in subsection (8) of this section, determine the TEDE to the MEI for existing and proposed emission controls, and without any emission controls (the potential-to-emit) using the release rates from subsection (13) of this section. Provide all input data used in the calculations.

The total effective dose equivalent to the maximally exposed individual using 40 CFR 261, Appendix D, methodology is presented in Table 11-1. The maximally exposed individual is located 9.9 kilometers west of the 100 Area. The dose conversion factors used were derived from the EPA-approved code CAP-88 (EPA 1990). The projected dose for each individual radionuclide was calculated by multiplying the projected annual emission from Table 10-1 by the dose conversion factor. The resulting dose is $7.23 \mathrm{E}+01 \mathrm{mrem}$.

The total effective dose equivalent to the maximally exposed individual using good engineering judgment of projected emissions is presented in Table 11-2. The maximally exposed individual is located 9.9 kilometers west of the 100 Area. The dose conversion factors used were derived from the EPA-approved code CAP-88 (EPA 1990). The projected dose for each individual radionuclide is calculated by multiplying the projected annual emission by the dose conversion factor. The resulting dose is $9.48 \mathrm{E}-04 \mathrm{mrem}$.

The 1994 calendar year emissions (Table 10-3) for the 105-KE Basin would result in a dose of $2.28 \mathrm{E}-04 \mathrm{mrem} /$ year to the maximaliy exposed individual located 9.9 kilometers west of the 100 Area. The projected dose for each individual radionuclide is calculated by multiplying the projected annual emission by the dose conversion factor. The dose was calculated by the EPA-approved code CAP-88 (EPA 1990). 
DOE/RL-95-65, Rev. 0

$08 / 95$

1

2

3

4

5

This page intentionally left blank. 
Table 11-1. Total Effective Dose Equivalent to the Maximally Exposed Individual Using Projected Emissions Based on 40 CFR 61, Appendix D, Methodology and CAP-88 Dose Conversion Factors.

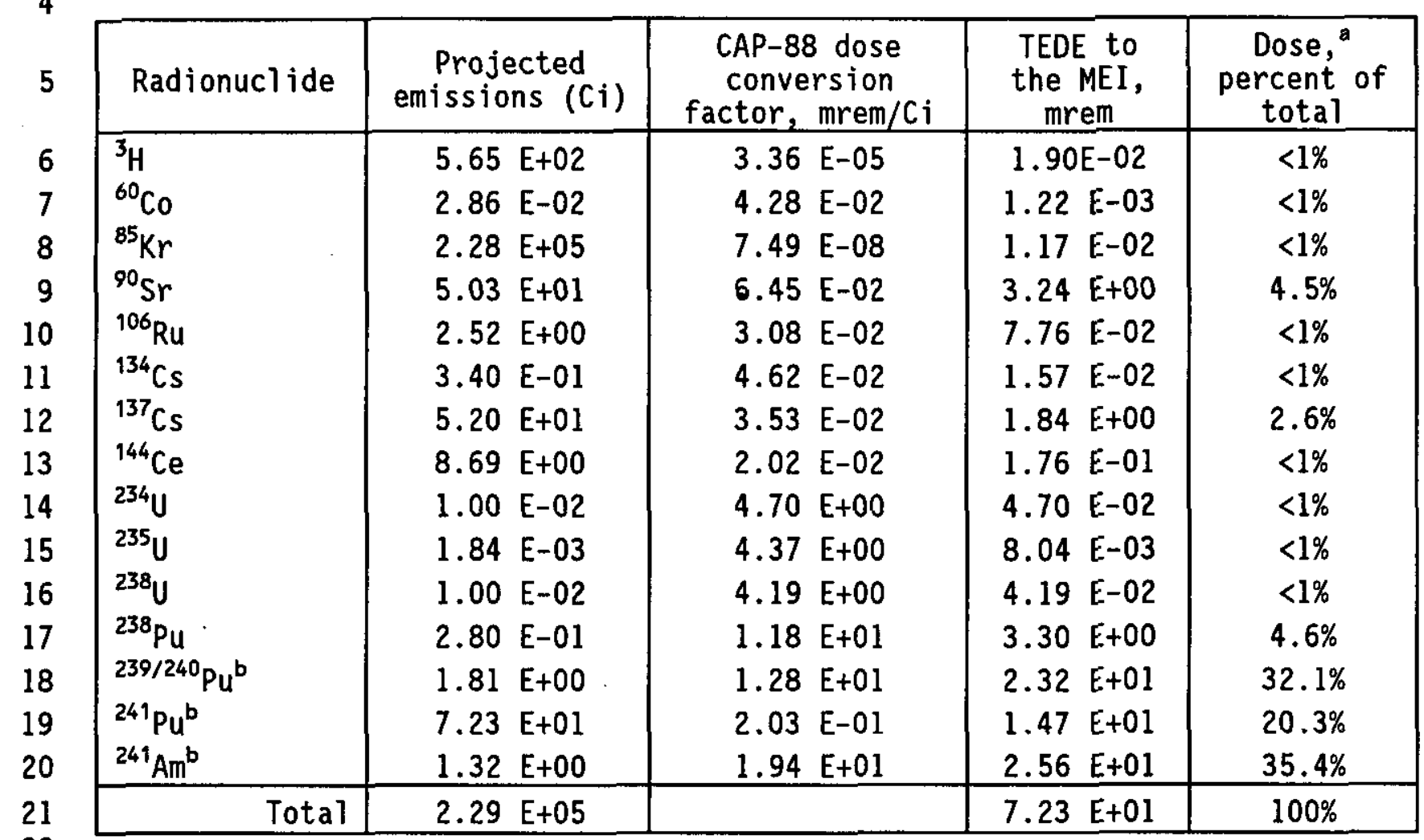

${ }^{a}$ Column may not add up to $100 \%$ because of rounding off.

badionuclides that could contribute greater than 10 percent of the potential to emit TEDE to the MEI.

Example calculation for ${ }^{3} \mathrm{H}$ :

$5.65 \mathrm{E}+02 \mathrm{Ci}$ of ${ }^{3} \mathrm{H} \times 3.36 \mathrm{E}-05 \mathrm{mrem} / \mathrm{Ci}$ of ${ }^{3} \mathrm{H}=1.90 \mathrm{E}-02 \mathrm{mrem}$ of ${ }^{3} \mathrm{H}$.

The following radionuclides contributed to less than $1 \%$ of the radionuclide source term; ${ }^{89} \mathrm{Sr},{ }^{95} \mathrm{Zr},{ }^{95} \mathrm{Nb}$, and ${ }^{103} \mathrm{Ru}$. (Curie concentrations were in the E-05 to E-09 range.)

$\mathrm{C} i=$ curie.

MEI = maximally exposed individual. mrem $=$ millirem.

TEDE = total effective dose equivalent. 
Table 11-2 ${ }^{a}$. Total Effective Dose Equivalent to the Maximally Exposed Individual Using CAP-88 Dose Conversion Factors for the Good Engineering Judgment.

\begin{tabular}{rl|c|c|c|c|c|}
\cline { 2 - 6 } 4 & Radionuclide & $\begin{array}{c}\text { Projected } \\
\text { Emissions } \\
\text { (Ci/yr) }\end{array}$ & $\begin{array}{c}\text { CAP-88 Dose } \\
\text { Conversion } \\
\text { Factor, } \\
\text { mrem/Ci }\end{array}$ & $\begin{array}{c}\text { TEDE to } \\
\text { the MEI, } \\
\text { mrem }\end{array}$ & $\begin{array}{c}\text { Dose }{ }^{\mathrm{b}} \text { percent } \\
\text { of total }\end{array}$ \\
5 & ${ }^{60} \mathrm{Co}$ & $1.1 \mathrm{E}-05$ & $4.28 \mathrm{E}-02$ & $4.71 \mathrm{E}-07$ & $<1 \%$ \\
6 & ${ }^{90} \mathrm{Sr}$ & $5.6 \mathrm{E}-04$ & $6.45 \mathrm{E}-02$ & $3.61 \mathrm{E}-05$ & $3.8 \%$ \\
7 & ${ }^{106} \mathrm{Ru}$ & $2.4 \mathrm{E}-05$ & $3.08 \mathrm{E}-02$ & $7.39 \mathrm{E}-07$ & $<1 \%$ \\
8 & ${ }^{137} \mathrm{Cs}$ & $4.8 \mathrm{E}-04$ & $3.53 \mathrm{E}-02$ & $1.69 \mathrm{E}-05$ & $1.8 \%$ \\
9 & ${ }^{238} \mathrm{Pu}$ & $5.2 \mathrm{E}-06$ & $1.18 \mathrm{E}+01$ & $6.14 \mathrm{E}-05$ & $6.5 \%$ \\
10 & ${ }^{239 / 240} \mathrm{Pu}$ & $3.1 \mathrm{E}-05$ & $1.28 \mathrm{E}+01$ & $3.97 \mathrm{E}-04$ & $41.9 \%$ \\
11 & ${ }^{241} \mathrm{Pu}$ & $4.0 \mathrm{E}-05$ & $2.03 \mathrm{E}-01$ & $8.12 \mathrm{E}-06$ & $0.9 \%$ \\
12 & ${ }^{241} \mathrm{Am}$ & $2.2 \mathrm{E}-05$ & $1.94 \mathrm{E}+01$ & $4.27 \mathrm{E}-04$ & $45.1 \%$ \\
\cline { 2 - 7 } 13 & Total & $1.2 \mathrm{E}-03$ & & $9.48 \mathrm{E}-04$ & $100 \%$ \\
\hline
\end{tabular}

${ }^{a}$ This table does not contain tritium ${ }^{3} \mathrm{H}$. Using $1.2 \mathrm{Ci} / \mathrm{yr}{ }^{3} \mathrm{H}$, as discussed in Section 10-2, and dose conversion factor of $3.36 \mathrm{E}-05 \mathrm{mrem} / \mathrm{Ci}$, a dose of $4.0 \mathrm{E}-05 \mathrm{mrem} / \mathrm{yr}$ would result.

${ }^{b}$ Column may not add up to $100 \%$ due to rounding off.
$\mathrm{Ci} / \mathrm{yr}$
MEI
= curie per year.
$\mathrm{mrem} / \mathrm{Ci}$
TEDE
= maximally exposed individual.
= millirem per curie.
= total effective dose equivalent. 
- 1 Table 11-3. Total Effective Dose Equivalent to the Maximally Exposed 2 Individual Using CY 1994 Emissions, using CAP-88 Dose Conversion Factors. 3

\begin{tabular}{|c|c|c|c|c|}
\hline Radionuclide & $\begin{array}{c}\text { Actual } \\
\text { Emissions } \\
(\mathrm{C} i / \mathrm{yr})\end{array}$ & $\begin{array}{c}\text { CAP-88 Dose } \\
\text { Conversion } \\
\text { Factor, } \\
\text { mrem } / \mathrm{C} i\end{array}$ & $\begin{array}{c}\text { TEDE to } \\
\text { the MEI, } \\
\text { mrem }\end{array}$ & $\begin{array}{c}\text { Dose }^{a} \\
\text { (percent of } \\
\text { total) }\end{array}$ \\
\hline${ }^{60} \mathrm{Co}$ & $3.6 E-07$ & $4.28 \mathrm{E}-02$ & $1.54 \mathrm{E}-08$ & $<1.0$ \\
\hline${ }^{90} \mathrm{Sr}$ & 4.6 E-05 & $6.45 E-02$ & 2.97 E-06 & 1.3 \\
\hline${ }^{106} \mathrm{Ru}$ & $2.3 E-06$ & $3.08 E-02$ & 7.08 E-08 & $<1.0$ \\
\hline${ }^{125} \mathrm{Sb}$ & $9.1 \quad E-07$ & 0.0146 & $1.33 E-08$ & $<1.0$ \\
\hline${ }^{137}$ Cs & $9.6 \quad E-05$ & $3.53 \mathrm{E}-02$ & $3.39 \mathrm{E}-06$ & 1.5 \\
\hline${ }^{154} \mathrm{Eu}$ & $1.6 E-06$ & $2.69 E-02$ & $4.30 \quad E-08$ & $<1.0$ \\
\hline${ }^{155} \mathrm{Eu}$ & 1.1 E-06 & $4.90 \mathrm{E}-03$ & 5.39 e-09 & $<1.0$ \\
\hline${ }^{238} \mathrm{Pu}$ & 1.2 E-06 & $1.18 E+01$ & $1.42 \mathrm{E}-05$ & 6.2 \\
\hline${ }^{239 / 240} \mathrm{Pu}^{\mathrm{b}}$ & 7.7 E-06 & $1.28 E+01$ & 9.86 E-05 & 43.2 \\
\hline${ }^{241} \mathrm{Pu}$ & $4.0 \quad E-05$ & $2.03 \mathrm{E}-01$ & $8.1 \quad E-06$ & 3.6 \\
\hline${ }^{241} \mathrm{Am}^{\mathrm{b}}$ & 5.6 E-06 & $1.94 E+01$ & $1.09 \mathrm{E}-04$ & 47.7 \\
\hline Total & $1.6 \mathrm{E}-04$ & & $2.28 \mathrm{E}-04$ & 100.0 \\
\hline
\end{tabular}



badionuclides that could contribute greater than $10 \%$ of the potential to emit TEDE to the MEI.

$\mathrm{Ci} / \mathrm{yr}$

MEI

$\mathrm{mrem} / \mathrm{C} \mathbf{i}$

TEDE
= curie per year.

= maximally exposed individual.

$=$ millirem per curie.

= total effective dose equivalent. 


\subsection{FACILITY LIFETIME (Requirement 17)}

Provide an estimate of the lifetime for the facility process with the emission rates provided in this application.

Currently, it is expected the $K$ Basins will continue to operate for at least another 4 years storing fuel. For the SNF, there is a two-phase strategy for packaging and moving the sludge and fuel from $\mathrm{K}$ Basins. The two-phase strategy moves the fuel to a newly constructed staging and storage facility by the year 2000, where the fuel is staged for stabilization. When a stabilization facility is constructed, the fuel will be cycled through a stabilization process and returned to the staging and storage facility for dry interim (40 year) storage. 
DOE/RL-95-65, Rev. 0

08/95

This page intentionally left blank. 


\subsection{TECHNOLOGY STANDARDS (Requirements 18)}

Indicate which of the following control technology standards have been considered and will be complied with in the design and operation of the emission unit(s) described in this application.

Modifications to emission control process equipment (water treatment system) are proposed. The modifications to the water treatment system will restore out of service equipment and are considered replacement in kind; therefore, incorporation of the control technology standards into the definitive design process are not applicable.

During the other activities described in the NOC, good engineering practices will be employed to reduce airborne emissions. 
DOE/RL-95-65, Rev. 0

$08 / 95$

1

2

4

5

This page intentionally left blank. 


\subsection{REFERENCES}

ANS, 1988, Design criteria for an Independent Spent Fuel Storage Installation (Water Pool Type), ANS 57-7-1988, American Nuclear Society, LaGrange, Illinois.

DOE-RL, 1993, Application for Approval of Modification for the 105-KE Basin Encapsulation Activity, DOE/RL-93-14, U.S. Department of Energy, Richland Operations Office, Richland, Washington.

DOE-RL, 1994, "Radionuclide Air Emissions Report for the Hanford Site, Calendar Year 1993", June 1994, DOE/RL-94-51, U.S. Department of Energy, Richland Operations Office, Richland, Washington.

DOE-RL, 1995, "Radionuclide Air Emissions Report for the Hanford Site, Calendar Year 1994", June 1995, DOE/RL-95-49, U.S. Department of Energy, Richland Operations Office, Richland, Washington.

EPA, 1990, The Clean Air Act Assessment Package - 1988 (CAP-88), A Dose and Risk Assessment Methodology for Radionuclide Emissions to Air, Vols. 1-3, U.S. Environmental Protection Agency, Washington, D.C.

WHC, 1991a, Facility Effluent Monitoring Plan for K Area Fuel Storage Basin, WHC-EP-0497, Westinghouse Hanford Company, Richland, Washington.

WHC, 1991b, Unit Dose Calculation Methods and Summary of Facility Effluent Monitoring Plan Determinations, WHC-EP-0498, Westinghouse Hanford Company, Richland, Washington.

WHC, 1993a, Test Report - 100K Basin Air Flow Effluent Volume Test, WHC-SD-NR-TRP-015, West inghouse Hanford Company, Richland, Washington.

WHC, 1993b, Transport Mechanism of Radionuclides in 105-KE Fuel Storage Basin to Airborne Effluent Release, WHC-SD-NR-ES-016, Westinghouse Hanford Company, Richland, Washington.

WHC, 1993c, BARCT Assessment for 105-KE Encapsulation Activity, WHC-SD-NR-TI-052, Westinghouse Hanford Company, Richland, Washington.

WHC, 1993d, Operations Safety Requirements - $100 \mathrm{KE}$ and KW Fuel Storage Basins, WHC-SD-WM-0SR-006, Westinghouse Hanford Company, Richland, Washington.

WHC, 1994a, Safety Analysis Report - N Reactor Fuel, WHC-SD-WM-SAR-062, Rev. 1, Westinghouse Hanford Company, Richland, Washington.

WHC, 1994b, Hanford Spent Fuel Inventory Baseline, WHC-SD-SNF-TI-001, Westinghouse Hanford Company, Richland, Washington. 
1 WHC, 1995a, An Assessment of KW Basin Radionuclide Activity When Opening SNF 2 Canisters, WHC-SD-SNF-006, Westinghouse Hanford Company, Richland, 3 Washington.

4

5 WHC, 1995b, 105-K Basin Material Design Basis Feed Description for Spent 6 Nuclear Fuel Project Facilities, WHC-SD-SNF-TI-009, Westinghouse Hanford 7 Company, Richland, Washington. 
DOE/RL-95-65, Rev. 0

$08 / 95$

\section{APPENDIX A}

DISCUSSION OF BEST AVAILABLE RADIONUCLIDE CONTROL TECHNOLOGY

6 
D0E/RL-95-65, Rev. 0

08/95

This page intentionally left. blank. 
DOE/RL-95-65, Rev. 0

$08 / 95$

\title{
APPENDIX A
}

\section{DISCUSSION OF BEST AVAILABLE RADIONUCLIDE CONTROL TECHNOLOGY}

Best available radionuclide control technology (BARCT) is defined by Washington Administrative Control Code (WAC) 246-247-030 as follows:

\begin{abstract}
"Technology that will result in a radionuclide emission limitation based on the maximum degree of reduction for radionuclides from any proposed newly constructed or significantly modified emission units that the licensing authority determines is achievable on a case-bycase basis. A BARCT compliance demonstration must consider energy, environmental, and economic impacts, and other costs through examination of production processes, and available methods, systems and techniques for control of radionuclide emissions. A BARCT compliance demonstration is the conclusion of an valuative process that results in the selection of the most effective control technology from all known feasible alternatives. In no event shall application of BARCT result in emissions of radionuclides that could exceed the applicable standards of WAC 246-247-040. Control technology that meets BARCT requirements also meets ALARCT requirements."
\end{abstract}

A BARCT assessment (WHC 1993C) was prepared for the 105-KE Basin encapsulation activity. The BARCT assessment studied the economic impacts of installing several HEPA filtration systems in the 105-KE Basin. The BARCT assessment revealed that installing HEPA filtration on the 105-KE Bas in was not cost effective. Based on the projected emissions described in this NOC, it is recommended that the water treatment system continue as BARCT for the 105-KE Basin. 
DOE/RL-95-65, Rev, 0

08/95

This page intentionally left blank. 


\section{DISTRIBUTION}

\section{OFFSITE}

A. W. Conkl in, Head

Air Emissions and Defense Waste Section

Division of Radiation Protection

State of Washington Department of Health

Airdustrial Park Building 5, LE-13

01 ympia, Washington 98504-0095

P. G. Millam, Acting Director

Air and Toxics Division

U.S. Environmental Protection Agency

Region 10

Mail Stop AT-082

1200 Sixth Avenue

Seattle, Washington 98101

W. Burke

Confederated Tribes of the Umatilla

Indian Nation

P. 0. Box 638

Pendleton, Oregon 97801

D. Powaukee

Nez Perce Tribe

P. 0. Box 365

Lapwai, Idaho 93540

R. Jim, Manager

Environmental Restoration/ Waste Management Program

Yakama Indian Nation

P. 0. Box 151

Toppenish, Washington 98948

ONSITE

U.S. Department of Energy,

MSIN

Richland Operations office

R. G. Holt

S7-41

H. M. Rodriguez

A5- 15

E. D. Sellers

S7-41

OSTI (2)

Reading Room (2)

ᄂ8-07

H2-53

Pacific Northwest Laboratory

Hanford Technical Library

K1-11 


\section{DISTRIBUTION (cont)}

Westinghouse Hanford Company

C. Defigh-Price

R. G. Gant

J. G. Granger (5)

J. J. Luke

G. C. Mooers

C. C. Pitkoff

D. S. Takasumi

WHC Central Files $\times 3-79$

$\times 3-79$

$\mathrm{H} 6-25$

H6-25

R3-11

R3-86

$\times 3-85$

L8-04 